\title{
Experimental investigation of a tank-in-tank heat storage unit utilizing stable supercooling of sodium acetate trihydrate
}

\author{
EngImair, Gerald; Furbo, Simon; Dannemand, Mark; Fan, Jianhua
}

Published in:

Applied Thermal Engineering

Link to article, DOI:

10.1016/j.applthermaleng.2019.114709

Publication date:

2020

Document Version

Peer reviewed version

Link back to DTU Orbit

Citation (APA):

Englmair, G., Furbo, S., Dannemand, M., \& Fan, J. (2020). Experimental investigation of a tank-in-tank heat storage unit utilizing stable supercooling of sodium acetate trihydrate. Applied Thermal Engineering, 167, [114709]. https://doi.org/10.1016/j.applthermaleng.2019.114709

\section{General rights}

Copyright and moral rights for the publications made accessible in the public portal are retained by the authors and/or other copyright owners and it is a condition of accessing publications that users recognise and abide by the legal requirements associated with these rights.

- Users may download and print one copy of any publication from the public portal for the purpose of private study or research.

- You may not further distribute the material or use it for any profit-making activity or commercial gain

- You may freely distribute the URL identifying the publication in the public portal 


\section{Journal Pre-proofs}

Experimental investigation of a tank-in-tank heat storage unit utilizing stable supercooling of sodium acetate trihydrate

Gerald Englmair, Simon Furbo, Mark Dannemand, Jianhua Fan

PII:

S1359-4311(19)32179-9

DOI: https://doi.org/10.1016/j.applthermaleng.2019.114709

Reference: ATE 114709

To appear in:

Applied Thermal Engineering

\section{APPLIED}

THERMAL

ENGINEERING

28 March 2019

Received Date:

19 November 2019

Revised Date:

20 November 2019

Please cite this article as: G. Englmair, S. Furbo, M. Dannemand, J. Fan, Experimental investigation of a tank-intank heat storage unit utilizing stable supercooling of sodium acetate trihydrate, Applied Thermal Engineering (2019), doi: https://doi.org/10.1016/j.applthermaleng.2019.114709

This is a PDF file of an article that has undergone enhancements after acceptance, such as the addition of a cover page and metadata, and formatting for readability, but it is not yet the definitive version of record. This version will undergo additional copyediting, typesetting and review before it is published in its final form, but we are providing this version to give early visibility of the article. Please note that, during the production process, errors may be discovered which could affect the content, and all legal disclaimers that apply to the journal pertain.

(C) 2019 Published by Elsevier Ltd. 


\title{
Experimental investigation of a tank-in-tank heat storage unit utilizing stable supercooling of sodium acetate trihydrate
}

\author{
Gerald Englmair ${ }^{1,2^{*}}$, Simon Furbo ${ }^{1}$, Mark Dannemand ${ }^{1}$ and Jianhua Fan ${ }^{1}$ \\ ${ }^{1}$ Department of Civil Engineering, Technical University of Denmark, Brovej 118, 2800 Kgs. Lyngby, Denmark \\ ${ }^{2}$ Sino-Danish Center for Education and Research, 380 Huaibeizhuang, Huairou district, Beijing, China
}

\begin{abstract}
A cylindrical heat storage prototype was designed to utilize sodium acetate trihydrate (SAT) composite with $2 \%$ wt. extra water and 3\%wt. of liquid polymeric solution for combined short and long-term heat storage. It was manufactured with inexpensive standard components of water stores. It contained 1501 of SAT composite in the inner tank and 591 of water in the mantle surrounding the inner tank and in a spiral heat exchanger going through the inner tank. The concept of stable supercooling of SAT and the heat transfer properties of the store filled with water or the SAT composite were studied. Results showed that $27 \mathrm{kWh}$ of heat was stored between $25^{\circ} \mathrm{C}$ and $90{ }^{\circ} \mathrm{C}$, where the energy storage capacity of the composite was determined to be $21.3 \mathrm{kWh}$. This was $76 \%$ higher than for a water heat store of the same volume. After a storage period in supercooled state at ambient temperature, $11.5 \mathrm{kWh}$ (long-term capacity) of heat was discharged when the SAT composite solidified. This value corresponds to a heat of fusion of $207 \mathrm{~kJ} / \mathrm{kg}$. During charge and discharge in periods with solidification, the heat exchange capacity rates did not change with increase of flow rates. With discharge flow rates of $2 \mathrm{l} / \mathrm{min}$ applied in the mantle surrounding, thermal stratification was utilized. Thus, flow temperatures higher than the average SAT composite temperature resulted in liquid state. By additional use of the spiral, the discharge power reached $15 \mathrm{~kW}$. During solidification the heat transfer was constantly decreasing, which resulted in a rather low discharge power. In building applications, heat transfer limitation could be overcome by discontinuous discharge via the mantle with intervals of 2-24 hours. Thus, thermal power of up to $4 \mathrm{~kW}$ was achieved and the outlet temperature was close to the average temperature of the SAT composite.
\end{abstract}

Keywords: Heat storage testing; Phase change material; Stable supercooling; Combined short and long-term heat storage; Domestic heating. 


\section{Nomenclature}

\begin{tabular}{|c|c|c|c|}
\hline \multicolumn{2}{|c|}{ Symbols } & \multirow[b]{2}{*}{$T R F$} & \multirow[b]{2}{*}{ temperature recovery factor (-) } \\
\hline$c_{p}$ & specific heat capacity $(\mathrm{kJ} / \mathrm{kg} \mathrm{K})$ & & \\
\hline$C$ & energy storage capacity $(\mathrm{kWh})$ & $\dot{V}$ & volume flow rate $(1 / \mathrm{min})$ \\
\hline$H X C R$ & heat exchange capacity rate $(\mathrm{W} / \mathrm{K})$ & \multicolumn{2}{|c|}{ Greek letters } \\
\hline$\Delta h$ & $\begin{array}{l}\text { specific heat of fusion during solidification } \\
\text { from supercooled state }(\mathrm{kJ} / \mathrm{kg})\end{array}$ & $\rho$ & density $(\mathrm{kg} / \mathrm{l})$ \\
\hline$k$ & heat loss coefficient $(\mathrm{W} / \mathrm{K})$ & $\sigma$ & standard deviation $(\%, \mathrm{~K})$ \\
\hline$L$ & latent heat of fusion $(\mathrm{kJ} / \mathrm{kg})$ & \multicolumn{2}{|c|}{ Abbreviations } \\
\hline$\varnothing$ & diameter $(\mathrm{m})$ & DHW & domestic hot water \\
\hline$Q$ & thermal energy, heat $(\mathrm{kWh})$ & & \\
\hline$\dot{Q}$ & thermal power $(\mathrm{kW})$ & HTF & heat transfer fluid \\
\hline$t$ & time $(\mathrm{h})$ & LabVIEW & $\begin{array}{l}\text { laboratory virtual instrument engineering } \\
\text { workbench }\end{array}$ \\
\hline$T$ & temperature $\left({ }^{\circ} \mathrm{C}\right)$ & $\mathrm{PCM}$ & phase change material \\
\hline $\bar{T}$ & average temperature $\left({ }^{\circ} \mathrm{C}\right)$ & SAT & sodium acetate trihydrate \\
\hline$\Delta T$ & temperature difference $(\mathrm{K})$ & $\mathrm{SH}$ & space heating \\
\hline
\end{tabular}

\section{Introduction}

Due to the mismatch of renewable energy resources and demand patterns of thermal household services, efficient heat storage is needed for domestic dwellings. In this context, research on novel materials and processes aims for more compact heat storage solutions with moderate heat losses over several days or weeks.

\subsection{Sodium acetate trihydrate composites for heat storage}

Sodium acetate trihydrate (SAT) has a melting point of $58{ }^{\circ} \mathrm{C}$ and a latent heat of fusion of $264 \mathrm{~kJ} / \mathrm{kg}$ [1]. It was identified as a suitable phase change material (PCM) for heat storage in households for space heating and domestic hot water supply [2]. SAT can cool down to the ambient temperature without solidifying and remain stable in supercooled state. When heat is in demand, solidification of the supercooled SAT can be initiated, for instance, by local cooling [3] or a seed crystal [4]. Other means such as ultrasonic waves, percussion vibration and mechanical systems were also investigated by Seo et al. [5], Zhou et al. [6] and Rogerson and Cardoso [7] respectively. The density of solid SAT in a closed sample solidified from supercooled state has been determined to be $1.24-1.28 \mathrm{~kg} / 1$ [8].

Supercooling is considered to hinder the conventional use of PCMs. Ways of reducing the supercooling of SAT have therefore been investigated $[9,10]$. Recently, a review on nucleation triggering methods for PCMs was conducted by Beaupere et al. [11]. Uzan et al. developed a multi-dimensional mathematical model for solidification process with supercooling, which was used to calculate heat transfer of the PCM heat storage system[12]. However, supercooling of PCM could be used as an advantage for long term heat storages as the supercooled PCM preserves latent heat of fusion almost heat loss free at ambient temperatures (i.e. no self-discharge). Sandnes and Rekstad measured stored energy as a function of temperature for supercooling salt hydrates [13]. Performances of PCM heat storages utilizing stable 
supercooling of SAT were investigated experimentally by Zhou and Xiang [14] and numerically by Zhou and Han [15]. There is no available theory to predict the maximum practical container size regarding supercooling stability of PCM, and limits need to be defined empirically by incremental scale-up [16]. Another critical factor for the utilization of supercooled PCM as a long-term heat storage is the stability or repeatability of the supercooled PCM. Dannemand et al. investigated experimentally supercooling stability of SAT composites in cylindrical latent heat storage units, showing that spontaneous crystallization occurred in $60-80 \%$ of the tests [17]. However, once supercooled status is reached at ambient temperatures, the PCM can be kept stable for months or even years in intact closed container. The investigation by Englmair et al. [18] revealed that supercooled SAT was kept stable for 71 days in a heat storage unit before solidification was activated by seed particles [3].

Additives are needed to prevent separation of dissolved and undissolved sodium acetate when SAT is supercooled below its melting temperature [19]. SAT composites with thickening agents and graphite were reported to overcome this problem by increasing thermal conductivity [20], which is advantageous for heat transfer during solidification. During supercooling of SAT however, liquid additives are considered to be better because natural convection improves the heat transfer of heat exchangers. Kong et al. [21] investigated different stabilizers and concluded that SAT composites with HD 310, a liquid polymer prototype solution, had high heat of fusion after supercooling to room temperature.

\subsection{PCM heat stores}

PCMs can be used in low temperature applications [22], where a high potential for building applications was found [2]. PCMs with optimized melting temperatures can be utilized as passive thermal energy storage in the building envelope, leading to notable reduction of heat demand [23]. Among PCMs, salt hydrates are attractive due to their relatively high phase change enthalpies [24].Because of heat transfer restrictions during PCM solidification, different heat exchangers have been investigated. Liu and Groulx [25] studied the heat transfer inside a horizontal cylindrical latent heat storage. The performance of internal bundle heat exchangers was investigated by Lopez-Navarro et al. [26]. Shell-and-tube heat exchangers [27] and macro encapsulated PCM in water vessels [28] were tested for sensible-latent heat storage. Niyas et al. measured thermal performance of a lab-scale shell-and tube latent heat storage prototype [29]. The solidification process of supercooled SAT was first modelled by Ma et al. [30], based on measured thermos-physical properties. Delgado et al carried out experimental analysis of a coiled stirred tank containing a low cost PCM emulsion as a thermal energy storage system [31]. Castell et al. presented experimental investigations of the influence of tank design and flow rate, etc. on heat transfer rate of a coil-in-tank PCM cold storage system [32]. Lafri et al. carried out experimental investigation on combined sensible and latent heat storage in two different configurations of tank filled with PCM. Both heat storage tanks had a coil-in-tank heat exchanger [33]. Coil-in-tank PCM heat storages of different design were also investigated by Kabbara et al. [34] and Tayssir et al. [35]. A latent heat storage with a plate heat exchanger for solar cooling applications was investigated experimentally by Palomba et al. [36].

The concept of thermal energy storage utilizing supercooled SAT mixtures was firstly discussed by Barrett and Best in 1985 [37]. Commercialization of such thermal energy storages is however a challenge. Desgrosseilliers designed and evaluated a modular supercooling PCM heat storage device, which had penitential of commercial applications for indoor heating [38]. At the Technical University of Denmark, the concept of utilizing stable supercooling of SAT has been first applied to flat [39] and cylindrical [17] prototype heat storage units. A segmented PCM heat storage, consisting of four flat prototype units each containing approximately $200 \mathrm{~kg}$ SAT composite, was designed for application in a solar heating 
system and tested in combination with a water tank [18]. It was later applied for demonstration of a novel solar combisystem, utilizing stable supercooling of SAT [40]. The potential annual system performance in a Danish Passive House scenario was studied by system simulation, considering application of evacuated tubular collectors [41]. It was found that heat storage units could be charged several times during winter with surplus of wind energy and in summer, spring and autumn by solar collectors.

Rathgeber et al. [42] have found that acceptable energy storage capacity costs of heat stores in buildings ranged from about $1 € / \mathrm{kWh}$ for seasonal heat storage to $429 € / \mathrm{kWh}$ for daily utilization. For industrial use SAT is available in large quantities, market prices are typically below $0.5 € / \mathrm{kg}$. The more annual storage cycles in a certain application could be achieved, the higher the economic benefits would be. For heat storage units containing $200 \mathrm{~kg}$ SAT composites in solar combi-systems [41], monthly utilization of a heat storage capacity in the range of $15-27.4 \mathrm{kWh}$ could be assumed. Then, cost-competitive heat storage prices would be in the range of $100-460 €$. Thus, inexpensive heat exchanger and PCM container design is required.

\subsection{Scope}

In this article, a cylindrical tank-in-tank heat storage with an internal spiral heat exchanger is presented. It is the first heat store utilizing stable supercooling of SAT composites built with low-cost standard components from industry, which were designed for water tanks. Experimental investigations were conducted to clarify the following aspects:

- Can stable supercooling of SAT be utilized with this heat store?

- Energy storage capacities for full charge, short and long-term heat storage based on a series of test cycles

- How does the SAT composite perform in comparison to water?

- Comparison of spiral- and mantle heat exchanger performance with different flow rates

- Is the heat transfer from the SAT composite to water sufficient to enable domestic hot water (DHW) and space heating (SH) supply in terms of flow temperature and power?

The presented results are valuable knowledge in pursue of developing economically attractive compact thermal energy storages that are more efficient than water storages. The investigation shows the potential differences in water and PCM storages and elucidates the way of operating a low cost PCM heat storage for optimal performance.

\section{Energy storage capacity calculation}

For energy storage capacity calculation of the heat store $\left(C_{\text {store }}\right)$ the masses of pure SAT, additives, container, and heat transfer fluid (HTF) must be considered. The heat capacities of additives, the container and the HTF were calculated by the temperature-dependent specific heat capacity $\left(c_{p}\right)$ multiplied with the temperature difference at the start and at the end of the heat transfer process. $C_{\text {store }}$ results from the sum of the capacity of storage components:

$$
C_{\text {store }}(\mathrm{kWh})=C_{S A T}+C_{\text {additive }}+C_{\text {container }}+C_{H T F}
$$

For $\mathrm{c}_{\mathrm{p}}$-calculation of water (as HTF) the IAWPS standard [43] was used. The specific heat capacity of pure SAT has been determined by Araki et al. [44], where for solid state from $30^{\circ} \mathrm{C}$ to $58^{\circ} \mathrm{C}$ Equation 2 and for the liquid state from $30{ }^{\circ} \mathrm{C}$ to $80^{\circ} \mathrm{C}$ Equation 3 was found:

$$
c_{p, \text { solid }}\left(\frac{\mathrm{kJ}}{\mathrm{kgK}}\right)=0.811+4.06 \times 10^{-3} \times T_{\text {absolute }}
$$




$$
c_{p, \text { liquid }}\left(\frac{\mathrm{kJ}}{\mathrm{kgK}}\right)=1.56+4.27 \times 10^{-3} \times T_{\text {absolute }}
$$

Where $T_{\text {absolute }}$ is the temperature of SAT in $\mathrm{K}$. To the best knowledge of authors this is the most comprehensive study of SAT's heat capacity, it was therefore assumed that Equations $2-3$ are applicable in the temperature range of $20-90{ }^{\circ} \mathrm{C}$.

For SAT, three energy storage capacities are relevant:

$$
\begin{gathered}
C_{S A T}(\mathrm{kWh})=m_{S A T} \times\left[\int_{T_{\text {ambient }}}^{T_{\text {phase }} c_{p, \text { solid }}} d T+L+\int_{T_{\text {phase change }}}^{T_{\text {final }}} c_{p, \text { liquid }} d T\right] / 3600 \\
C_{S A T \text { short }- \text { term }}(\mathrm{kWh})=m_{S A T} \times \int_{T_{\text {ambient }}}^{T_{\text {final }}} c_{p, \text { liquid }} d T / 3600 \\
C_{S A T \text { long-term }}(\mathrm{kWh})=m_{S A T} \times \Delta h=m_{S A T} \times\left[L-\int_{T_{\text {ambient }}}^{\left.T_{\text {phase change }}\left(c_{p, l i q u i d}-c_{p, \text { solid }}\right) d T\right] / 3600}\right.
\end{gathered}
$$

The total energy storage capacity of SAT $\left(C_{S A T}\right)$ is calculated for the full operation range, from ambient temperature ( $\left.T_{\text {ambient }}\right)$ to the temperature at full charge $\left(T_{\text {final }}\right)$, by employing Equation 4 . Its short-term capacity $\left(C_{S A T \text { short-term }}\right)$ results from supercooling to ambient condition and is calculated according to Equation 5. Its long-term capacity $\left(C_{S A T \text { long-term }}\right)$ is the remaining heat of fusion after supercooling, calculated according to Equation 6 . The latent heat of fusion $(L)$ at $58{ }^{\circ} \mathrm{C}$ ( $\left.T_{\text {phase change }}\right)$ has been determined to be in the range of $240 \mathrm{~kJ} / \mathrm{kg}$ [45] to $264 \mathrm{~kJ} / \mathrm{kg}$ [1]. The specific heat of fusion during solidification from supercooled state $(\Delta h)$ is temperature-dependent. $\Delta h$ is based on $L$, reduced by the difference of $c_{p}$ in between liquid and solid states during supercooling. Experimental investigations on $\Delta h$ have been conducted by Kong et. al [21], where heat contents of well-performing SAT composites have resulted in values between 200 and $220 \mathrm{~kJ} / \mathrm{kg}$ at $20^{\circ} \mathrm{C}$.

Specific energy contents of SAT in calculated states are shown in Fig. 1. For passivation of nucleation seeds the liquid phase of SAT needs to exceed a temperature of $77^{\circ} \mathrm{C}$ [44] to be able to supercool to ambient temperature.

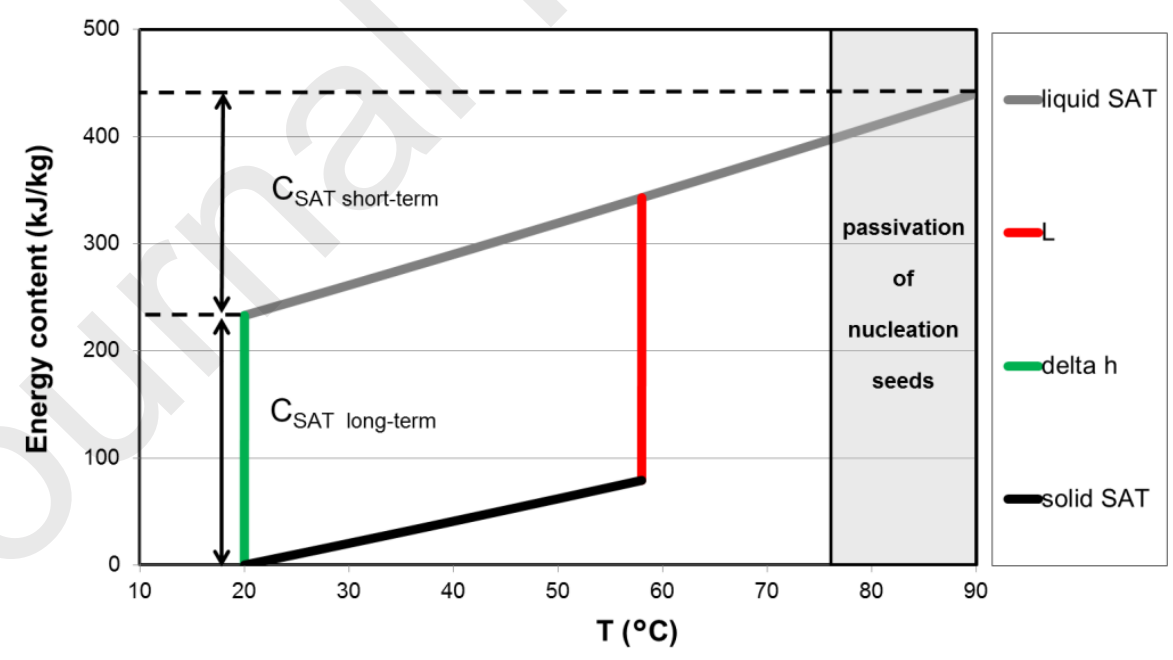

Fig. 1. Specific energy contents of SAT as a function of temperature. 


\section{Method}

\subsection{Heat storage design}

Inexpensive heat stores are needed for building application, which has to be addressed when utilizing SAT composites for heat storage. Therefore, a cylindrical heat storage prototype was built with standard components of water heat stores (scheme in Fig. 2 a). It was manufactured by the Danish company NILAN A/S. A steel tank with an outer diameter of $0.45 \mathrm{~m}$ contained the SAT composition and a steel spiral heat exchanger. It was situated in the centre of another steel tank with a diameter of $0.5 \mathrm{~m}$, to realize heat exchange via its outer surface. The volume between the two tanks was filled with water, used as HTF, forming a mantle heat exchanger. An installer friendly, modular design was realized by rectangular shaped foam insulation and a metal cabinet with sufficient space for piping (Fig. 2 b).

a)

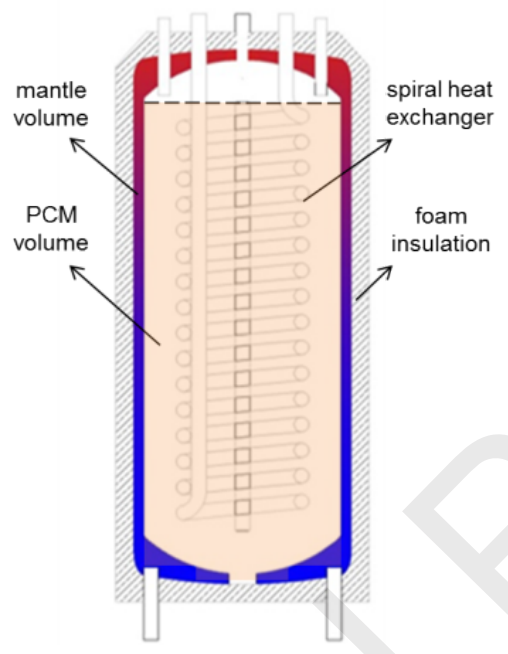

b)

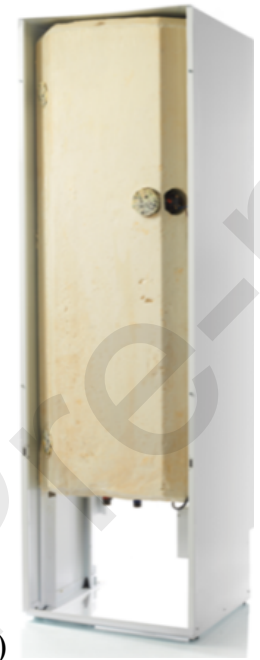

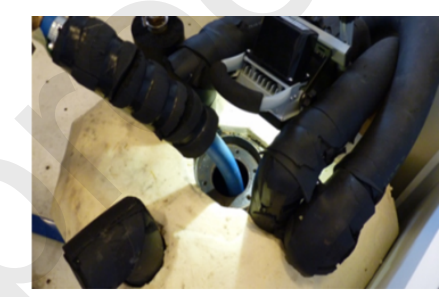

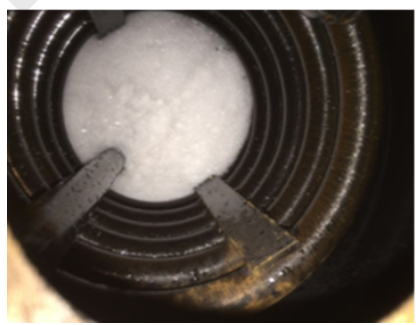

Fig. 2. a) Schematic drawing (intersection); b) Picture of the cylindrical heat storage; c) Filling of melted SAT composite in the inner tank of the store (top); View into the inner tank, partially filled with melted SAT composite (bottom).

For this work, a composite containing food-grade SAT (European standard 262i) from the German supplier IG Chemicals GmbH, 3 \%wt. of the liquid polymer solution HD 310 from the Chines company Suzhou Hongde Co. Ltd. and $2 \%$ wt. of extra water was chosen as PCM. The HD 310 solution is a carboxylate water mixture with a PH value of four. The melting point of the SAT composite is $58^{\circ} \mathrm{C}$.

Crystalline SAT and additives were mixed in two closed vessels of 100 1, which were then placed for 72 hours in an oven at $90{ }^{\circ} \mathrm{C}$. Afterwards, the melted SAT composite was filled into the pre-heated inner tank by means of a tube (Fig. 2 c). The melted SAT composite covered a height of $1.12 \mathrm{~m}$, measured after the first full storage charge to a temperature of $90{ }^{\circ} \mathrm{C}$. The resulting specifications of the heat store are presented in Table 1. 
Table 1. Specification of the heat store.

\begin{tabular}{|c|c|c|c|c|c|}
\hline \multicolumn{2}{|c|}{ Container } & \multicolumn{2}{|c|}{ Spiral heat exchanger } & \multicolumn{2}{|c|}{ SAT composite } \\
\hline Inner tank height: & $1.20 \mathrm{~m}$ & Outer coil $\varnothing$ : & $0.35 \mathrm{~m}$ & Maximal volume at $90^{\circ} \mathrm{C}$ : & approx. $158 I^{*}$ \\
\hline Outer tank height: & $1.25 \mathrm{~m}$ & Number of windings: & 15.5 & Mass: & $200 \mathrm{~kg}$ \\
\hline Mass including coil: & $140.8 \mathrm{~kg}$ & Coil height: & $0.8 \mathrm{~m}$ (centred) & SAT purity: & $>98.5 \%$ wt. [46] \\
\hline HTF volume: & 591 & Outer tube $\varnothing$ : & $0.032 \mathrm{~m}$ & $c_{p, \text { solid }}$ & $2.09 \mathrm{~kJ} / \mathrm{kg} \mathrm{K}$ at $41.5^{\circ} \mathrm{C}$ [44] \\
\hline $\begin{array}{l}\text { Heat transfer area } \\
\text { mantle: }\end{array}$ & $1.6 \mathrm{~m}^{2}$ & $\begin{array}{l}\text { Heat transfer area } \\
\text { spiral: }\end{array}$ & $1.8 \mathrm{~m}^{2}$ & $C_{p, \text { liquid }}$ & $3.04 \mathrm{~kJ} / \mathrm{kg} \mathrm{K}$ at $74^{\circ} \mathrm{C}$ [44] \\
\hline
\end{tabular}

* Considering a density of $1.27 \mathrm{~kg} / \mathrm{l}$

\subsection{Test setup}

The layout of the test setup is presented in Fig. 3. A hydraulic circuit with two parallel lines for spiral- and mantle heat exchangers was built. For charging, an electrical heater with a power of $9 \mathrm{~kW}$ was used. Heat was discharged via a heat exchanger to a laboratory cooling circuit, where the cooling power was controlled via flow rate settings. In this way, inlet temperatures $\left(T_{i n}\right)$ around $25{ }^{\circ} \mathrm{C}$ for cooling the heat store were attained. Valves and pumps were set manually for either charging or discharging operation. A membrane vessel was connected to the top of the inner tank to avoid builtup of pressure due to volume changes of the SAT composite [8].

Each line was equipped with volume flow meters. Flow rates to the spiral- $\left(\dot{V}_{\text {spiral }}\right)$ and to the mantle heat exchanger $\left(\dot{V}_{\text {mantle }}\right)$ were controlled via string-valves. 5-junction thermopiles were installed to measure temperature differences $(\Delta T)$ between inlets and outlets of both lines, where additional thermocouples measured inlet- and outlet temperatures. The temperature of the inner tank was measured by thermocouples in 12 locations, where $T_{1}-T_{6}$ were distributed evenly in a centred line and $T_{7}-T_{12}$ were distributed in a distance of $0.19 \mathrm{~m}$ from the centre.

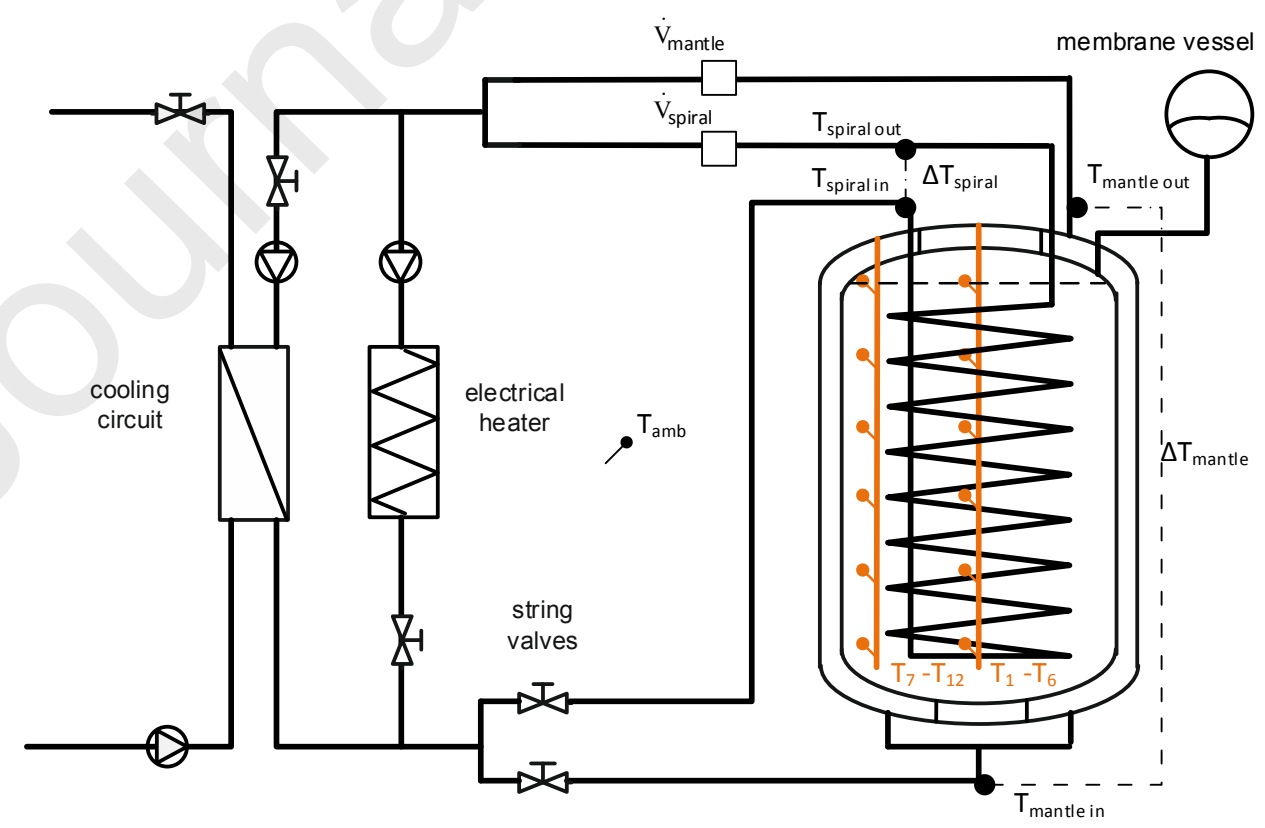

Fig. 3. Diagram of the hydraulic layout and main components of the test setup. 
Initially, two glass rods (Fig. 4 a) were used to separate thermocouples and wires from the SAT composite. During the $3^{\text {rd }}$ test cycles the central rod broke. It was therefore removed later and the thermocouples were reinstalled in direct contact to the SAT composite (Fig. 4 b). The ambient temperature was measured one meter from the heat store. Thermocouples and thermopiles were connected to a 16-channel thermocouple data acquisition module (NI9214). Flow meters were connected to a 32-channel digital input/output data acquisition module (NI9403). A LabVIEW program was used to read and to convert the signals every second into measurement values. Instant values were displayed on a monitor and the measurements were logged with minute-averaged values.

a)

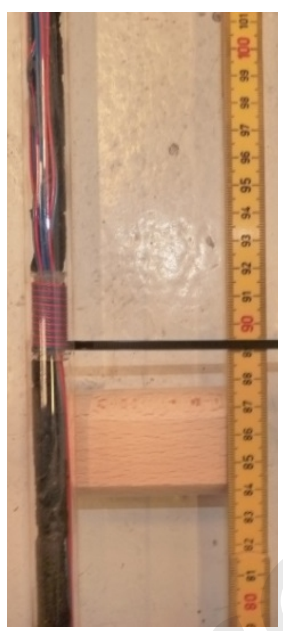

b)

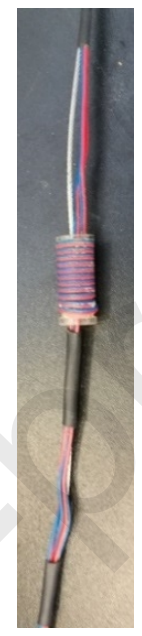

Fig. 4. Thermocouple installment in the inner tank: a) In glass rods; b) In contact with SAT composite alongside a steel rope.

An overview of measurement accuracy is given in Table 2, where the variations of readings have been analysed in accordance to the guide to the expression of uncertainty in measurement [47]. Variations represent the half value of the confidence-interval of a measurand in normal distribution, in which $95.4 \%(2 \sigma)$ and $68.2 \%(\sigma)$ of measured values occur. The data are based on performed calibration tests including the whole measurement chain (sensors, wires and National Instruments data acquisition system with module no. 9214 for thermocouple and thermopile readings and module no. 9403 for flow meter readings). Flow meter readings have been calibrated for the applied HTF flow range, according to manufacturer information. Afterwards, flow meter and temperature readings were tested for their random variation.

Table 2. Measurements and their accuracy.

\begin{tabular}{|c|c|c|c|c|}
\hline Measurand & Measurement device & $\begin{array}{c}\text { Random variation } \\
\text { including data }\end{array}$ & Distribution & Source \\
\hline$\dot{V}_{\text {mantle }}, \dot{V}_{\text {spiral }}$ & $\begin{array}{c}\text { Kamstrup Ultraflow 54, class } \\
2 \text { (EN 1434) }\end{array}$ & $0.5(\%)$ & normal $(\sigma)$ & $\begin{array}{c}\text { Calibration in accordance to } \\
\text { manufacturer information [48] }\end{array}$ \\
\hline $\begin{array}{c}T_{\text {mantle in, }}, T_{\text {mantle out }}, T_{\text {spiral in, }}, \\
T_{\text {spiral out, }} T_{\text {amb }}, T_{1}-T_{12}\end{array}$ & $\begin{array}{c}\text { T-type thermocouple } \\
\text { (copper/ constantan) }\end{array}$ & $0.3(\mathrm{~K})^{*}$ & normal $(2 \sigma)$ & Experimental data analysis \\
\hline$\Delta T_{\text {spiral, }} \Delta T_{\text {mantle }}$ & $\begin{array}{c}\text { 5-junction thermopile with } \\
\text { T-type thermocouples }\end{array}$ & $0.15(\mathrm{~K})$ & normal $(2 \sigma)$ & Experimental data analysis \\
\hline
\end{tabular}

* The maximum sensor uncertainty is $0.42 \mathrm{~K}[49]$

\subsection{Experimental tests}

Since the heat store was developed for SH and DHW supply in buildings, the following temperatures were considered 
for application:

- $T_{\text {ambient }}=25^{\circ} \mathrm{C}$ (room temperature)

- $T_{i n}=25^{\circ} \mathrm{C}$ (space heating return flow in temperature equilibrium with the room; optimum)

- $T_{\text {final }}=90^{\circ} \mathrm{C}$ (maximum temperature from heat source; e.g. solar heating system)

The energy storage capacity of the container and the HTF was determined by charging the cold store with empty inner tank. In the next step, the heat store was tested with water, filled to a height of $1.12 \mathrm{~m}$ in the inner tank. Its heat content was tested as reference by charging and discharging via spiral- and mantle heat exchangers, applied combined and individually with HTF flow rates of $2-10 \mathrm{l} / \mathrm{min}$.

The heat content and the heat transfer were tested with the SAT composite in a similar way. Fig. 5 shows the schematic development of the heat content during a test cycle, where the following test sequence was applied:

- Charging from ambient temperature with an initial thermal power of $9 \mathrm{~kW}$ and SAT composite in solid state. Full charge was reached when $T_{\text {in }}$ attained $90{ }^{\circ} \mathrm{C}$ and $T_{\text {out }}$ remained constant for about one hour. $C_{\text {store }}$ (defined in Equation 1) was calculated by deducting heat losses from the charged heat.

- Next, the sensible heat of the storage was discharged while the SAT composite supercooled in liquid state. The storage was discharged to ambient temperature. The discharged sensible heat (storage heat losses were included in the calculation), was defined as the short-term energy storage capacity of the store $\left(C_{\text {short-term }}\right)$.

- A resting period without heat losses followed, where the SAT composite remained in supercooled state.

- Afterwards, solidification of the SAT composite was initiated by a seed crystal inserted via a flange on top of the inner tank. Stored heat of fusion was then discharged. The long-term energy storage capacity of the storage $\left(C_{\text {long- }}\right.$ term) was defined as the discharge heat, including heat losses.

Several test cycles with combined and individual application of spiral- and mantle heat exchangers and variation of HTF flow rates have been conducted (Table 3). The following tests cycles differed from above mentioned procedure:

- During test cycle 2 supercooled SAT was recharged to $70{ }^{\circ} \mathrm{C}$ and then discharged to study $C_{\text {short-term }}$ without supercooling of the SAT composite.

- During test cycle 8, charging was interrupted when $T_{\text {out }}$ fell to $30^{\circ} \mathrm{C}$ and continued when $T_{\text {out }}$ reached the average PCM composite temperature $\left(\bar{T}_{P C M}\right)$. Manual seed injection was therefore conducted at $\bar{T}_{P C M}=33{ }^{\circ} \mathrm{C}$.

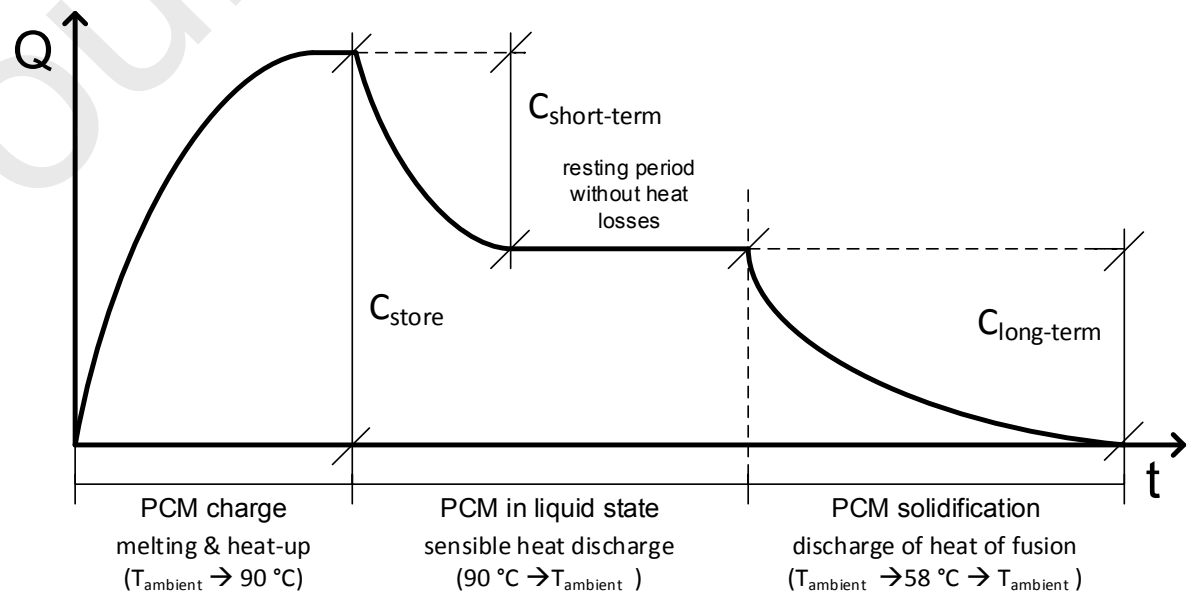

Fig. 5. Applied test cycles: Development of the storage heat content over time and definition of heat storage capacities. 


\subsection{Performance evaluation}

Thermal power to/ from the spiral- and mantle heat exchangers were calculated through heat balance to the HTF by employing Equation 7:

$$
\dot{Q}(\mathrm{~W})=\dot{V} \times c_{p} \times \rho \times \Delta T
$$

Where $\dot{V}$ is the measured volume flow rate of the HTF, $c_{p}$ is the specific heat capacity of the HTF at mean temperature between $T_{\text {in }}$ and $T_{\text {out }}$, and $\rho$ is the density of the HTF at $T_{\text {out }}$.

To determine heat losses, the store was charged by spiral- and mantle heat exchangers with $T_{i n}=70{ }^{\circ} \mathrm{C}$ a HTF flow rate of $2 \mathrm{l} / \mathrm{min}$. A steady state was reached when the heat inflow was equal to the heat losses, resulting in a constant outlet temperature. It lasted for about 12 hours, where the data of the last 2 hours was used to calculate the heat loss coefficient $(k)$ by employing Equation 8:

$$
k\left(\frac{\|}{K}\right)=\frac{\dot{Q}_{\text {spiral }}+\dot{Q}_{\text {mantle }}}{\frac{\mathrm{T}_{\text {mantle in }}+\mathrm{T}_{\text {mantle out }}}{2}-T_{\text {amb }}}
$$

$T_{i n}$ was calculated with the following relation:

$$
T_{\text {in }}\left({ }^{\circ} \mathrm{C}\right)=T_{\text {out }}-\Delta T
$$

The temperature recovery factor $(T R F)$ during charging and discharging was determined with Equation 10:

$$
T R F=\frac{T_{\text {in }}-T_{\text {out }}}{T_{\text {in }}-\bar{T}_{P C M}}
$$

Where $\overline{\mathrm{T}}_{\mathrm{PCM}}$ is the average SAT composite temperature. The TRF expresses the ratio of actual to ideal HTF temperature returning from the storage. TRF values above one may result from thermal stratification of the HTF in heat exchangers.

The heat exchange capacity rate $(H X C R)$ was used to evaluate the ability to transfer thermal energy between the HTF and the SAT composite:

$$
\operatorname{HXCR}\left(\frac{W}{\mathrm{~K}}\right)=\dot{V} \times c_{p} \times \rho \times \ln \left(\frac{T_{\text {in }}-\bar{T}_{P C M}}{T_{\text {out }}-\bar{T}_{P C M}}\right)
$$

$\bar{T}_{P C M}$ was calculated with a volume-based weight-model for inner tank measurements $\left(T_{1}-T_{12}\right)$. Fig. 6 shows the distribution and the weight of temperature readings, where the inner tank volume was idealised with a central cylinder and two annular spaces, divided into vertical segments $(0.2 \mathrm{~m}$ in height). Segments of the central cylinder corresponded to $T_{1}-T_{6}$, those of the outer annual space corresponded to $T_{7}-T_{12}$ and the central annual space corresponded to the mean temperature value of the central cylinder and the outer annular space. Because the upper segments were half filled, their temperatures were considered with half weight. 
a)

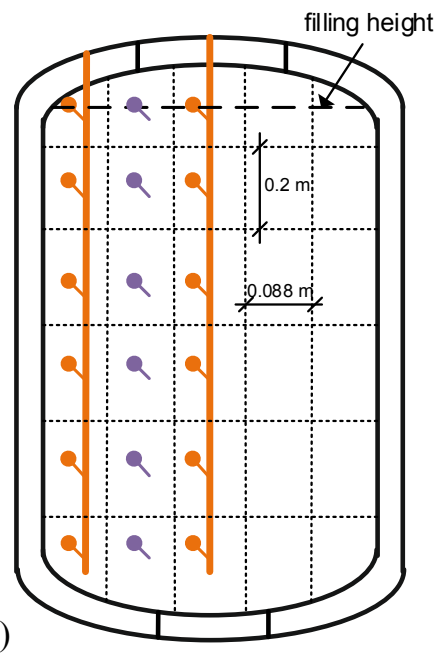

b)

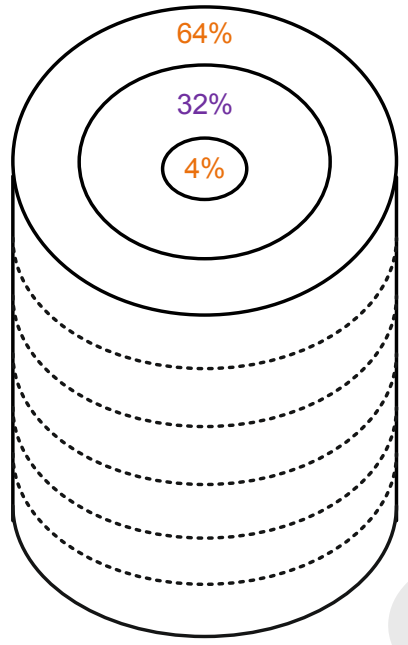

Fig. 6. Determination of $\bar{T}_{P C M}$ : a) Distribution of temperature values (measured in orange, calculated in purple) over the intersection of the heat store: b) Weight of temperature readings corresponding to the volume.

To compare heat transfer properties of different tests, average values of $T R F$ and $H X C R$ were calculated. The integration of $T R F$ and $H X C R$ over the heat content of the store $\left(Q_{\text {store }}\right)$ is illustrated for $T R F$ :

$$
T R F_{\text {average }}=\frac{\int_{\bar{T}_{P C M, 1} E}^{T_{P C M} E} d Q_{\text {store }}}{\int_{\bar{T}_{P C M 1}, 2}^{T_{P S t o r e}}}
$$

Intervals of $\overline{\mathrm{T}}_{P C M}$ were chosen in order to exclude the effect of heat-up and cool-down of heat exchangers: a) charge from $30{ }^{\circ} \mathrm{C}$ to $80^{\circ} \mathrm{C}$; b) discharge in liquid state from $80{ }^{\circ} \mathrm{C}$ to $30^{\circ} \mathrm{C}$; c) discharge during solidification from $58{ }^{\circ} \mathrm{C}$ to $35^{\circ} \mathrm{C}$.

\section{Results and discussion}

\subsection{Supercooling stability}

Table 3 presents supercooling temperatures and set flow rates during test cycles. In all 12 cycles, low supercooling temperatures were achieved. However, supercooling was only stable in test cycles 1, 2, 5, 7 and 8 in which solidification was manually initiated. In other tests uncontrolled crystallization occurred, potentially due to the following reasons:

- In cycle 3 and 4 one of the installed glass rods for internal temperature measurements (Fig. 4 a) was defective. Data analysis showed that SAT crystallization started from the bottom of the inner tank volume, where the rod was broken and therefore ambient air (containing fine solid particles as potential nucleation seeds) could enter the inner tank.

- During cycle 6 and 9-12 SAT crystallization started from the top of the inner tank volume. Later inspection showed a corroded top surface of the inner tank with traces of salt, which was not in contact with the SAT composite. It can be assumed that nucleation seeds could remain there and eventually fall on the supercooled SAT composite during cool-down. Other explanations could be that open thermocouple wires (Fig. 4 b) were not suitable for testing and that one of the top-flanges of the inner tank lost tightness.

Despite the open thermocouple wires and corroded inner tank surfaces low supercooling temperatures were achieved. 
Data of all tests could therefore be used for energy storage capacity and heat transfer analysis. For an improved heat store, the above mentioned problems could potentially be avoided by:

- Using oil instead of air in the expansion volume in the inner tank to avoid corrosion

- Design of the inner tank with a single, well-sealed opening for filling and pressure compensation

- No internal temperature monitoring

Table 3. Investigated test cycles with SAT composites.

\begin{tabular}{|c|c|c|c|c|c|c|}
\hline \multirow{2}{*}{ Test cycle } & \multirow{2}{*}{ Starting date } & \multirow{2}{*}{$\begin{array}{c}\text { Supercooling } \\
\text { temperature ( } \\
\left.\bar{T}_{P C M}\right)\end{array}$} & \multirow{2}{*}{$\begin{array}{l}\text { Resting } \\
\text { period }\end{array}$} & \multicolumn{3}{|c|}{$\begin{array}{c}\text { HTF flow rates } \\
\text { (spiral/ mantle heat exchanger) }\end{array}$} \\
\hline & & & & Charge & $\begin{array}{l}\text { Discharge in } \\
\text { liquid state }\end{array}$ & $\begin{array}{l}\text { Discharge during } \\
\text { solidification }\end{array}$ \\
\hline 1 & 12.06.2016 & $24^{\circ} \mathrm{C}$ & $24 \mathrm{~h}$ & $3 / 3.5 \mathrm{l} / \mathrm{min}$ & $6.5 / 6.5 \mathrm{l} / \mathrm{min}$ & $2 / 1.6 \mathrm{l} / \mathrm{min}$ \\
\hline 2 & 16.06 .2016 & $25^{\circ} \mathrm{C}$ & $10 \mathrm{~h}$ & $7 / 7 \mathrm{l} / \mathrm{min}$ & $5.5 / 5.5 \mathrm{l} / \mathrm{min}$ & $2 / 21 / \mathrm{min}$ \\
\hline 3 & 6.02 .2017 & $33^{\circ} \mathrm{C}$ & $\mathrm{Oh}$ & $5 / 5 \mathrm{l} / \mathrm{min}$ & $5 / 5 \mathrm{l} / \mathrm{min}$ & $5 / 51 / \mathrm{min}$ \\
\hline 4 & 13.02 .2017 & $34^{\circ} \mathrm{C}$ & $0 \mathrm{~h}$ & $5 / 5 \mathrm{l} / \mathrm{min}$ & $5 / 5 \mathrm{l} / \mathrm{min}$ & $5 / 5 \mathrm{l} / \mathrm{min}$ \\
\hline 5 & 20.03 .2017 & $24^{\circ} \mathrm{C}$ & $14 \mathrm{~h}$ & $5 / 5 \mathrm{l} / \mathrm{min}$ & $5 / 5 \mathrm{l} / \mathrm{min}$ & $2 / 21 / \min$ \\
\hline 6 & 30.03 .2017 & $30{ }^{\circ} \mathrm{C}$ & $0 \mathrm{~h}$ & $5 / 5 \mathrm{l} / \mathrm{min}$ & $2 / 2 \mathrm{l} / \mathrm{min}$ & $2 / 2 \mathrm{l} / \mathrm{min}$ \\
\hline 7 & 11.07.2017 & $26^{\circ} \mathrm{C}$ & $6 \mathrm{~h}$ & $10 / 10 \mathrm{l} / \mathrm{min}$ & $5 / 51 / \min$ & $5 / 5 \mathrm{l} / \mathrm{min}$ \\
\hline 8 & 14.07.2017 & $33^{\circ} \mathrm{C}$ & $\mathrm{Oh}$ & $10 / 10 \mathrm{l} / \mathrm{min}$ & $0 / 21 / \min$ & $0 / 2$ l/min \\
\hline 9 & 19.07.2017 & $24^{\circ} \mathrm{C}$ & $0 \mathrm{~h}$ & $7 / 7 \mathrm{I} / \mathrm{min}$ & $0 / 21 / \mathrm{min}$ & $0 / 2 \mathrm{l} / \mathrm{min}$ \\
\hline 10 & 27.07 .2017 & $27^{\circ} \mathrm{C}$ & $\mathrm{Oh}$ & $0 / 5 \mathrm{l} / \mathrm{min}$ & $2 / 0 \mathrm{l} / \mathrm{min}$ & $2 / 0 \mathrm{l} / \mathrm{min}$ \\
\hline 11 & 23.01.2018 & $30^{\circ} \mathrm{C}$ & $\mathrm{Oh}$ & $5 / 5 \mathrm{l} / \mathrm{min}$ & $2 / 2 \mathrm{l} / \mathrm{min}$ & $2 / 2 \mathrm{l} / \mathrm{min}$ \\
\hline 12 & 24.01 .2018 & $26^{\circ} \mathrm{C}$ & $\mathrm{Oh}$ & $5 / 5 \mathrm{l} / \mathrm{min}$ & $3 / 31 / \min$ & $3 / 31 / \min$ \\
\hline
\end{tabular}

\subsection{Proof of concept}

The development of stored heat $\left(Q_{\text {store }}\right)$ and the thermal power $(\dot{Q})$ during the $5^{\text {th }}$ test cycle is presented in Fig. 7 . The orange area displays data measured during charging (solid and liquid phases of SAT), the grey area marks data with SAT in liquid state and the blue area marks data during discharge after SAT composite solidification was initialized. The standard deviation $(\sigma)$ of a single data point of thermal power, related to sensors, data acquisition and calculation, was typically $+/-0.56 \%$. This value refers to an operation state with a HTF flow rate of $2 \mathrm{l} / \mathrm{min}$ and a temperature difference of $30 \mathrm{~K}$ between inlet- and outlet of the heat storage. Since minute-based datasets were used, the heat content calculation was sufficiently accurate for comparison of test cycles.

During charging from initially solid PCM state $27 \mathrm{kWh}$ of heat was stored. Thermal power started at $8 \mathrm{~kW}$ and fell below $7.5 \mathrm{~kW}$ after 2 hours. After 6 hours $\bar{T}_{P C M}$ reached $88^{\circ} \mathrm{C}$. It took additional 4 hours to reach a steady state with $\bar{T}_{P C M}$ at $90{ }^{\circ} \mathrm{C}$. Then the sensible heat of the store was discharged by cooling down to ambient temperature within 2 hours. Thermal power peaked at $34 \mathrm{~kW}$ when the cooling circuit was activated. The high discharge power was mainly due to discharging the 591 heated HTF in the mantle. Then a resting period of 15 hours was followed by manual seed crystal insertion. As consequence, $\bar{T}_{P C M}$ rose to $58^{\circ} \mathrm{C}$. Heat of fusion was discharged with thermal power peaking at $5.9 \mathrm{~kW}$. It took about 13 hours until $\bar{T}_{P C M}$ reached ambient conditions. 
In liquid SAT state, the prototype worked as sensible heat storage with a capacity of $15.5 \mathrm{kWh}$. After a period without heat losses, which could be extended to several months according to the author's experience with other prototype stores [18], $11.5 \mathrm{kWh}$ of heat was discharged. This proved that the storage unit could be used for combined short and long-term heat storage.

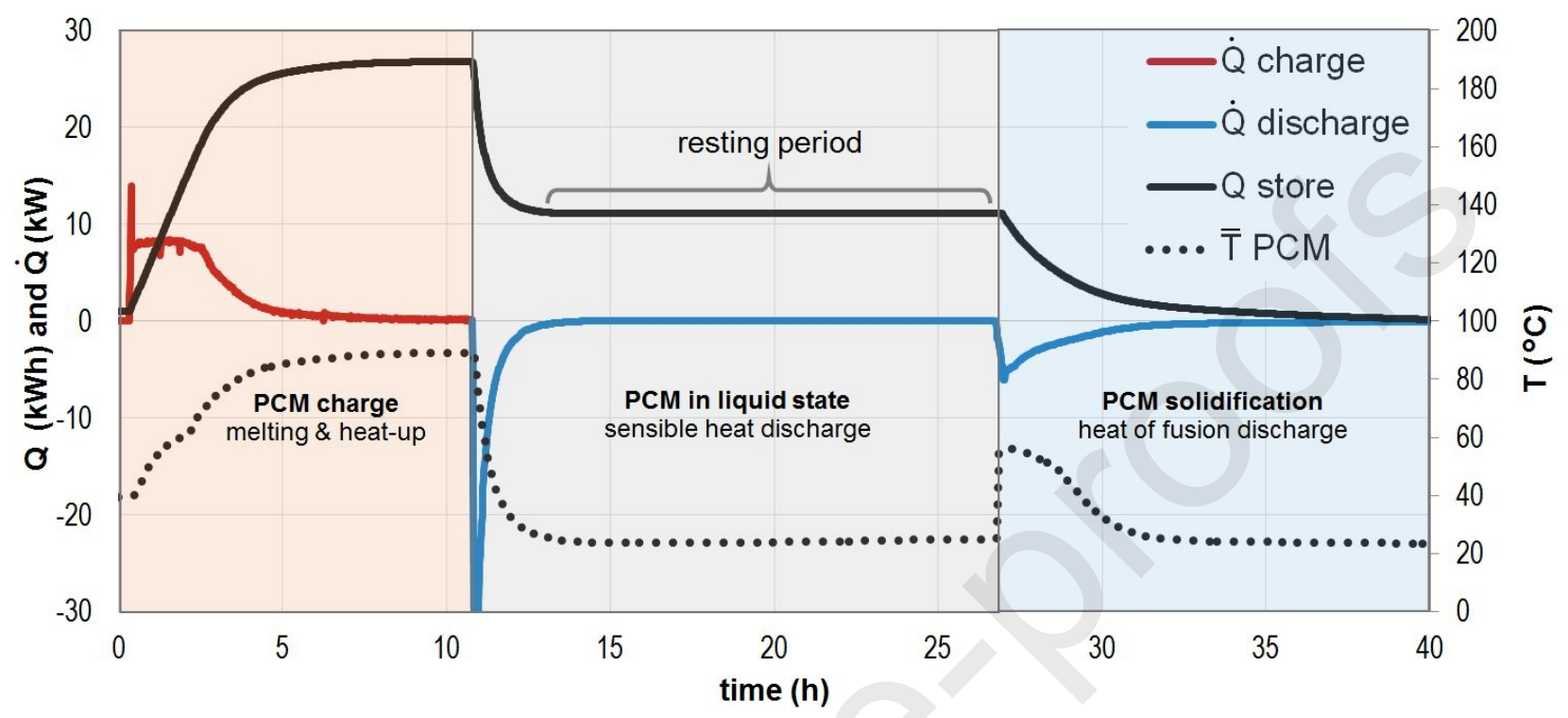

Fig. 7. Development of heat content, thermal power and temperature over time during the $5^{\text {th }}$ heat storage test cycle with SAT composite.

\subsection{Thermal capacities}

Determined energy storage capacities are presented in Table 4. The capacity of the container and the filled spiraland the mantle heat exchangers was $5.7 \mathrm{kWh}$, while $C_{\text {store }}$ was $27 \mathrm{kWh}$ with SAT composite. The storage capacity of the SAT composite $\left(C_{P C M}\right)$ was calculated to be $21.3 \mathrm{kWh}$, which was $76 \%$ higher than for water $\left(C_{\text {water }}=12.1 \mathrm{kWh}\right)$ filled in the inner tank. After heating up to $90{ }^{\circ} \mathrm{C}, 15.5 \mathrm{kWh}\left(C_{\text {short-term }}\right)$ of sensible heat was discharged as the PCM cooled down to supercooled state and $11.5 \mathrm{kWh}\left(C_{\text {long-term }}\right)$ were discharged after solidification was initialized at $25{ }^{\circ} \mathrm{C}$. This means that $43 \%$ of $C_{\text {store }}$ could be stored over long periods without sensible heat losses. The heat loss coefficient of the store was determined to be of $2.4 \mathrm{~W} / \mathrm{K}$ (Equation 8 ).

By heating up to $70^{\circ} \mathrm{C}$, it was ensured that nucleation seeds remained in the liquid SAT composite. The store provided then $21.8 \mathrm{kWh}$ of heat for short-term usage, utilizing SAT crystallization at $58^{\circ} \mathrm{C}$. $C_{\text {short-term }}$ was then $81 \%$ of $C_{\text {store }}$, which was higher than the capacity of the storage filled with water $\left(66 \%\right.$ of $C_{\text {store }}$ at $\left.90{ }^{\circ} \mathrm{C}\right)$.

Referring to the SAT composite mass, $\Delta h$ was determined to be $207 \mathrm{~kJ} / \mathrm{kg}$. This value is $7 \mathrm{~kJ} / \mathrm{kg}$ higher than found by a heat loss method [21] for a composition with $2 \%$ HD 310 and $2 \%$ extra water, where a lower supercooling temperature $\left(20^{\circ} \mathrm{C}\right)$ was applied. 
Table 4: Energy storage capacities of the store with water and SAT composite.

\begin{tabular}{|c|c|c|c|c|}
\hline Temperature range & \multicolumn{2}{|c|}{ Capacity (kWh) } & $\%$ & Reference \\
\hline \multirow{5}{*}{$\begin{array}{l}\text { Charge: } \\
25 \rightarrow 90{ }^{\circ} \mathrm{C}\end{array}$} & $C_{\text {container }}+C_{H T F:}$ & $5.7 \mathrm{kWh}$ & 21 & heat-up of empty store* \\
\hline & $C_{\text {store }}$ with water: & $17.8 \mathrm{kWh}$ & 66 & $\begin{array}{l}3 \text { charging tests (spiral, mantle and } \\
\text { combined) with } \dot{V}_{H T F}=10 \mathrm{l} / \mathrm{min}^{*}\end{array}$ \\
\hline & $C_{\text {water: }}$ & $12.1 \mathrm{kWh}$ & 45 & $C_{\text {store }}-C_{\text {container }}-C_{H T F}$ \\
\hline & $C_{\text {store }}$ with SAT composite: & $27 \mathrm{kWh}$ & 100 & test cycles: $2-11^{*}$ \\
\hline & $C_{P C M:}$ & $21.3 \mathrm{kWh}$ & 79 & $C_{\text {store }}-C_{\text {container }}-C_{H T F}$ \\
\hline $\begin{array}{l}\text { Discharge: } \\
90 \rightarrow 25^{\circ} \mathrm{C}\end{array}$ & $C_{\text {short-term }}$ with supercooling: & $15.5 \mathrm{kWh}$ & 57 & test cycles: $2,5^{\star *}$ \\
\hline $\begin{array}{l}\text { Discharge: } \\
70 \rightarrow 25^{\circ} \mathrm{C}\end{array}$ & $\begin{array}{l}C_{\text {short-term }} \text { without } \\
\text { supercooling: }\end{array}$ & $21.8 \mathrm{kWh}$ & 81 & test cycle: $2^{*}$ \\
\hline $\begin{array}{l}\text { Discharge: } \\
25 \rightarrow 25^{\circ} \mathrm{C}\end{array}$ & $C_{\text {long-term: }}$ & $11.5 \mathrm{kWh}$ & 43 & test cycles: $1-12^{*}$ \\
\hline
\end{tabular}

* Values from test cycles were adapted to the given temperature range (according to section 2)

$* *$ Exact temperature range applied

\subsection{Storage temperature development}

Fig. 8 shows the development of the average temperatures of water ( $\bar{T}_{\text {water }}$, blue curves) and SAT composite $\left(\bar{T}_{P C M}\right.$, black and grey curves) in the inner tank over measured $Q_{\text {store }}$ during charge. Store charging with water in the inner tank stopped at various temperatures, while with PCM charge finished above $85{ }^{\circ} \mathrm{C}$. The store was initially at ambient temperature, and then the average tank filling temperature $(\bar{T})$ rose with delay due to the heating up of both HTF and heat exchangers. From about $2 \mathrm{kWh}$ on, $\bar{T}_{\text {water }}$ was directly proportional to the heat content, independent from heat exchanger and flow rate selection. The method for determination of $\bar{T}$ was therefore valid.

$\bar{T}_{P C M}$ rose non-linear, due to combined sensible and phase change of SAT composite. The temperature of heat exchangers exceeded the melting temperature of SAT $\left(58{ }^{\circ} \mathrm{C}\right)$ around a heat content of $5 \mathrm{kWh}$, when SAT composite started to solidify around the heat exchanger surfaces. Higher HTF flow rates correspond to slightly lower $\bar{T}_{P C M}$. Slower increase of $\bar{T}_{P C M}$ was observed in the ranges of $45-55$ and $70-75{ }^{\circ} \mathrm{C}$ when transferred heat was merely consumed to melt SAT composite. This happened at significantly higher temperatures $\left(60-75^{\circ} \mathrm{C}\right)$ when only the mantle heat exchanger was applied, which means that the core of the PCM was melted significantly later. During all tests the bottom of the inner tank remained colder, the melting process was therefore accomplished around $\bar{T}_{P C M}=75{ }^{\circ} \mathrm{C}$ and $Q_{\text {store }}=24$ kWh. For more homogenous charging the spiral heat exchanger should be located at a lower position. 


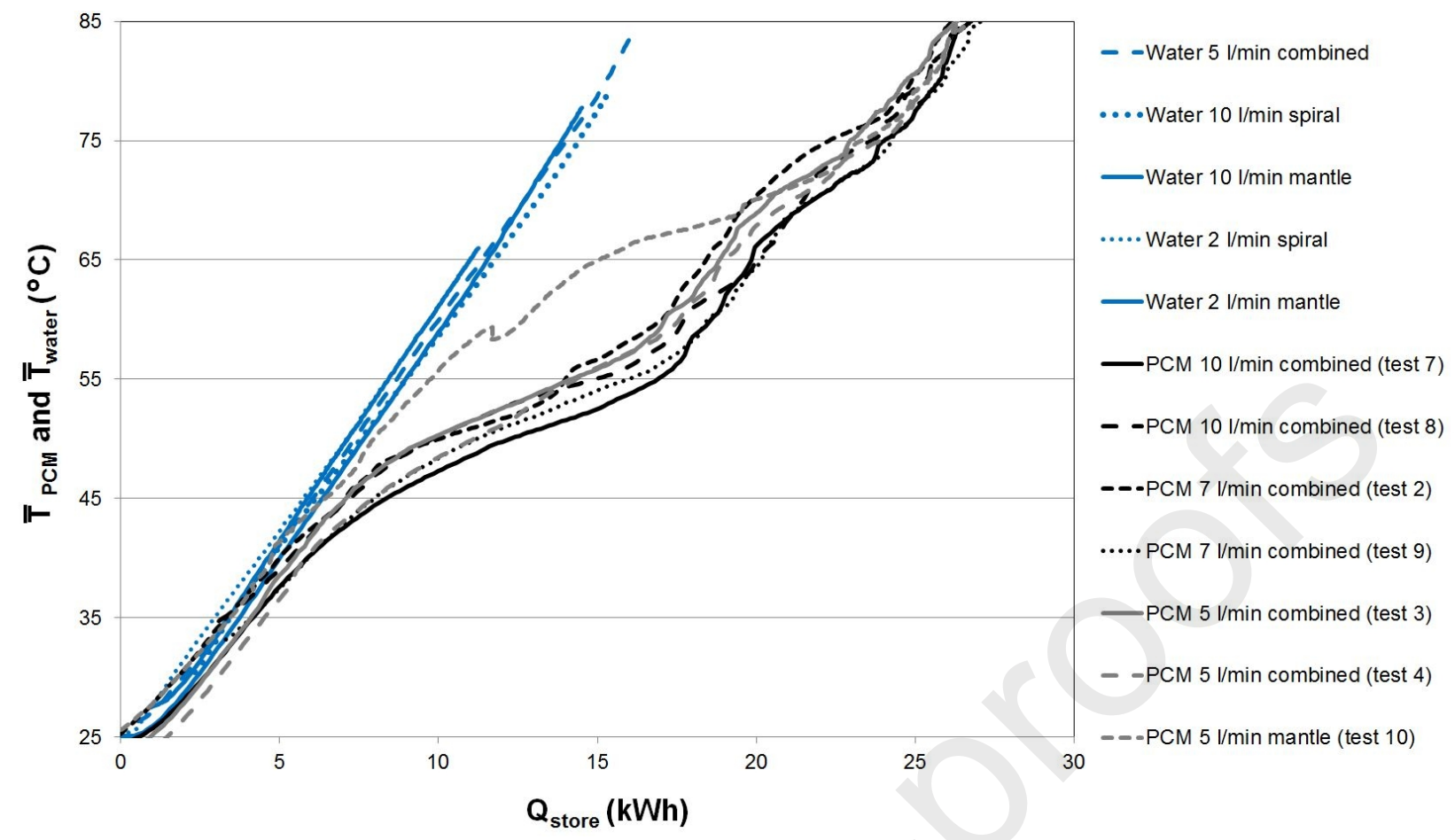

Fig. 8. Development of average water and SAT composite temperatures during charging.

Fig. 9 shows the development of $\bar{T}_{P C M}$ over $Q_{\text {store }}$ during charging and discharging for selected cycles. The measured energy contents were compared with calculated values according to Equations $1-4$ (black curves), using experimentally determined $C_{\text {store }}, C_{\text {container }}$ and $C_{H T F}$ as reference.

Data from combined charge tests (Fig. 8) was averaged and the resulting curve differed significantly from calculated energy content until phase change was accomplished at $75^{\circ} \mathrm{C}$. SAT solidification started at $26{ }^{\circ} \mathrm{C}$ during the $7^{\text {th }}$ and the $12^{\text {th }}$ test cycle and at $30{ }^{\circ} \mathrm{C}$ during the $6^{\text {th }}$ test cycle. Their heat storage capacities showed a high degree of similarity, indicating that the heat content did not significantly change after 12 test cycles, conducted over a time-span of 19 months.

From $75^{\circ} \mathrm{C}$ to $85^{\circ} \mathrm{C}$ the charge tests curve was slightly above the calculated states, because the HTF in the heat exchangers was warmer than $\bar{T}_{P C M}$. Discharge curves started below calculated values because the HTF in the heat exchangers was at ambient temperature, the curves therefore converged to calculated heat contents with falling $\bar{T}_{P C M}$.

In the temperature range of $86-90{ }^{\circ} \mathrm{C}$ (blue marked area) data were incomplete, due to heat storage cool-down before HTF flow was applied. Measurement data in the green marked area showed deviations to calculated states due to warmer HTF during charging and colder HTF during discharging, in comparison to $\bar{T}_{P C M}$. 


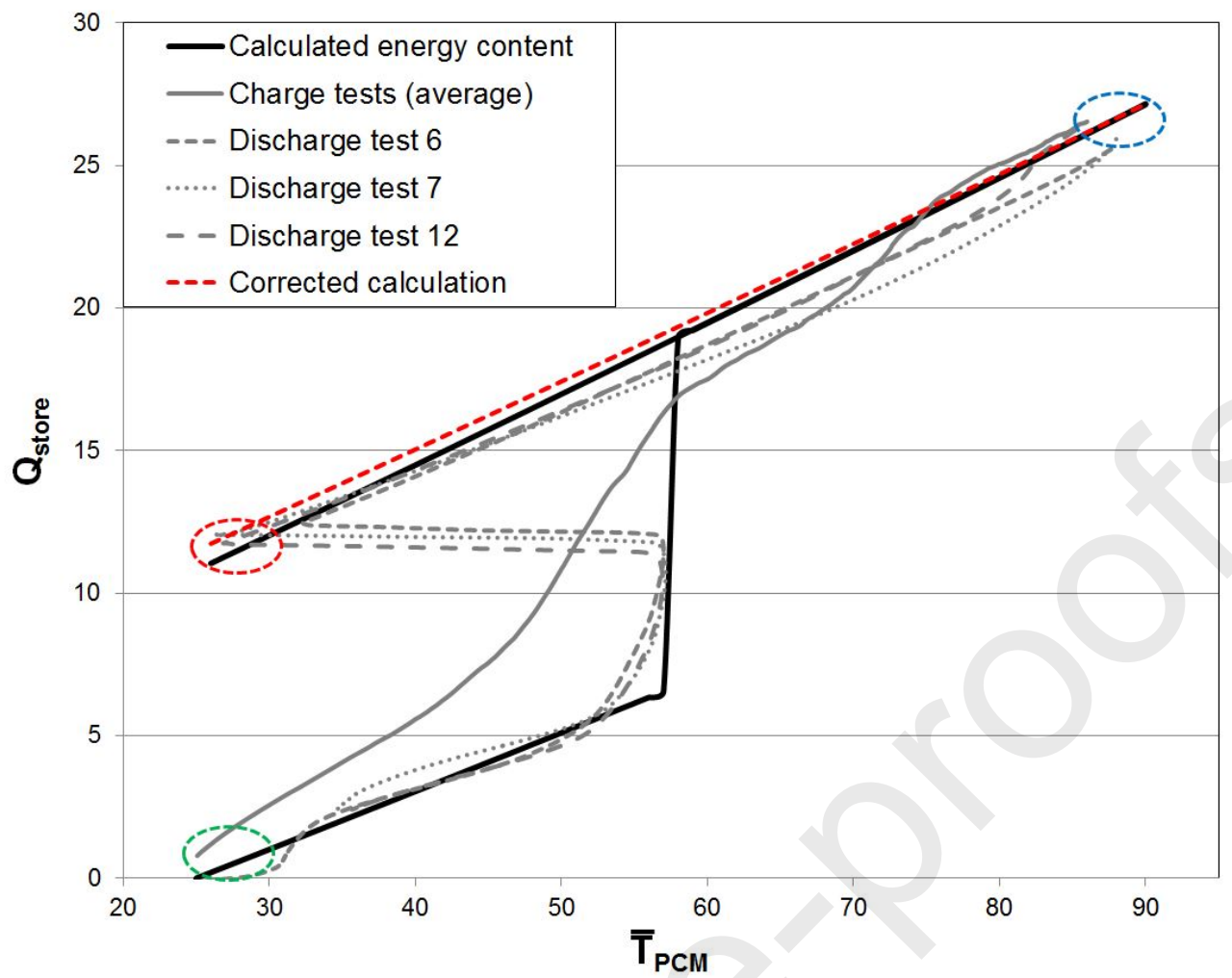

Fig. 9. Comparison of calculated and measured states during charging and discharging.

Data in the red marked area showed that measured $C_{\text {long-term }}\left(11.5 \mathrm{kWh}\right.$ at $\left.25{ }^{\circ} \mathrm{C}\right)$ was higher than calculated $\left(10.8 \mathrm{kWh}\right.$ at $\left.25^{\circ} \mathrm{C}\right)$. This indicated that Equation 3 is not valid for liquid SAT composites. Instead, Equation 13 should be applied:

$$
c_{p \text {, liquid }}\left(\frac{\mathrm{kJ}}{\mathrm{kg} \mathrm{K}}\right)=1.56+3.65 \times 10^{-3} \times T_{\text {absolute }}
$$

By corrected calculation $L$ was determined to be $238 \mathrm{~kJ} / \mathrm{kg} \mathrm{SAT}$, which had a minimal purity of 98.5\% (Table 1). This result corresponds to reference investigations of SAT containing $1 \%$ wt. of nucleating agents as impurity where $L$ was found to be $237-243 \mathrm{~kJ} / \mathrm{kg}$ SAT [45].

\subsection{Heat transfer analysis}

Fig. 10 presents the development of heat exchange capacity rate $(H X C R)$ and temperature recovery factor $(T R F)$ over $Q_{\text {store }}$ during charging processes with water (blue curves) and for cycles 7, 8 and 12 with SAT composites (black curves) filled in the inner tank of the store. At the beginning $\left(Q_{\text {store }}<2 \mathrm{kWh}\right)$ the HTF was heated up and values were therefore not representative.

The development of curves with SAT composite of both parameters was related to the melting behaviour (Fig. 8), values were therefore lower between 5 and $15 \mathrm{kWh}$, when PCM was merely melted and raised when PCM was merely heated up. The HXCR (Fig. 10 a) did not change in the flow rate range of $5-10 \mathrm{l} / \mathrm{min}$. This indicated that the flow regime of the HTF did not change and the heat transfer was limited by the SAT composite. Values ranged in between 250 and $400 \mathrm{~W} / \mathrm{K}$ being highest when SAT was merely heated up and convection of the melted SAT composite increased. As a consequence, $T R F$ (Fig. 10 b) was the highest with $\dot{\mathrm{V}}_{H T F}=5 \mathrm{l} / \mathrm{min}(0.32-0.4)$ and the lowest with $\dot{\mathrm{V}}_{H T F}=10 \mathrm{l} / \mathrm{min}$ 
$(0.2-0.25)$. This indicated that higher flow rates led to more homogeneous heat exchanger temperatures and higher return temperatures resulted.

During tests with water, individual use of the mantle heat exchanger showed rather constant $H X C R$ and $T R F$ values throughout the whole process, while individual use of the spiral heat exchanger showed slightly decreasing values down to $12 \mathrm{kWh}$, followed by a sharp decrease until fully charged. This shows that the spiral heat exchanger could not efficiently heat the bottom of the heat store. Combined application of heat exchangers resulted in raising $H X C R$ and $T R F$ up to 15 $\mathrm{kWh}$, followed by a decrease until fully charged. $T R F$ ranged from 0.5 to 0.6 during combined charge with $\dot{V}_{H T F}=10$ 1/min, which was about three times higher as with SAT composite.

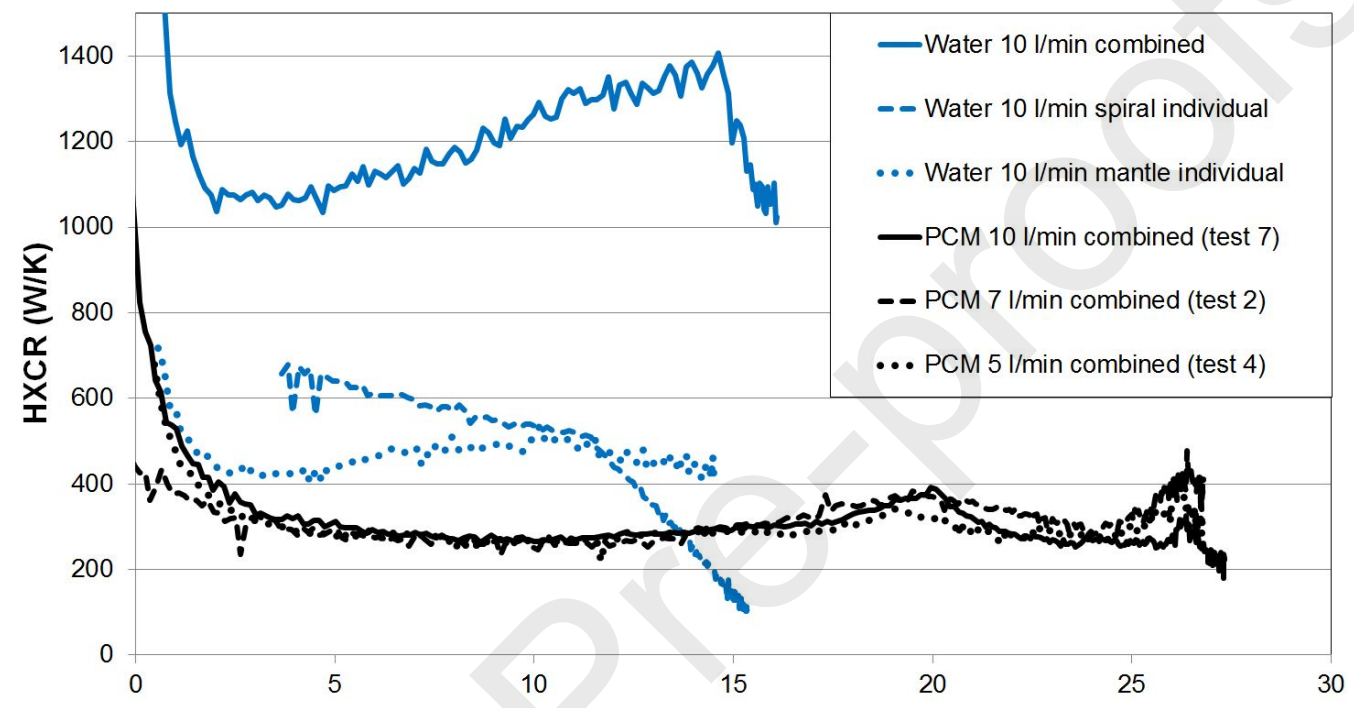

a)

$\mathbf{Q}_{\text {store }}(\mathrm{kWh})$

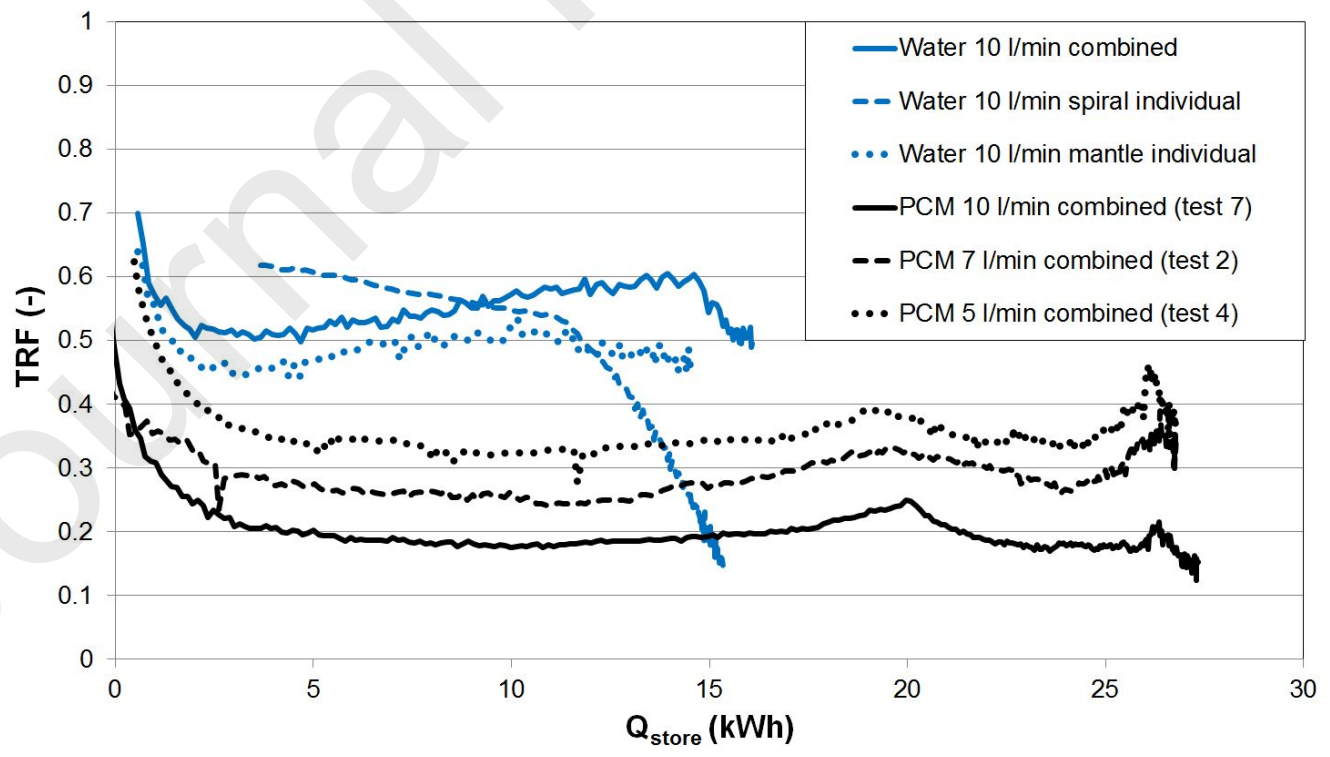

b)

Fig. 10. Development of heat transfer during charging: a) HXCR; b) TRF.

Fig. 11 presents the development of $T R F$ over $Q_{\text {store }}$ with SAT composite or water filling during discharge. Because of different supercooling degrees (Table 3) values were not comparable in between 11 and $13 \mathrm{kWh}$.

With liquid SAT composite individual application of spiral- and mantle heat exchangers with $\dot{V}_{H T F}=21 / \mathrm{min}$ resulted 
in higher temperature recovery factors than with water. The mantle heat exchanger achieved $T R F>1$ throughout cooldown of the PCM because of thermal stratification in the mantle HTF volume. When $\dot{V}_{H T F}=2 \mathrm{l} / \mathrm{min}$ was applied to both heat exchangers the development of TRF almost matched with the mantle heat exchanger. Similar to the charging of SAT composites, higher flow rates lead to significant lower $T R F$, indicating heat transfer restriction. Therefore, with $\dot{V}_{H T F}=5$ $1 /$ min the temperature recovery factor was higher with water than with SAT composite throughout discharge.

During SAT composite solidification TRF was significantly lower. No convection was possible and a growing layer of solid SAT composite, which had a low thermal conductivity, covered heat exchanger surfaces. With both heat exchangers in use, more heat could be discharged with a thinner solid PCM layer on their surfaces, in relation to individual heat exchanger application. With $\dot{V}_{H T F}=2 \mathrm{l} / \mathrm{min}$ individual heat exchanger operation performed therefore worse than combined operation. TRF was more than halved when $\dot{V}_{H T F}$ was raised from $21 / \mathrm{min}$ to $5 \mathrm{l} / \mathrm{min}$ in solid SAT composite state.

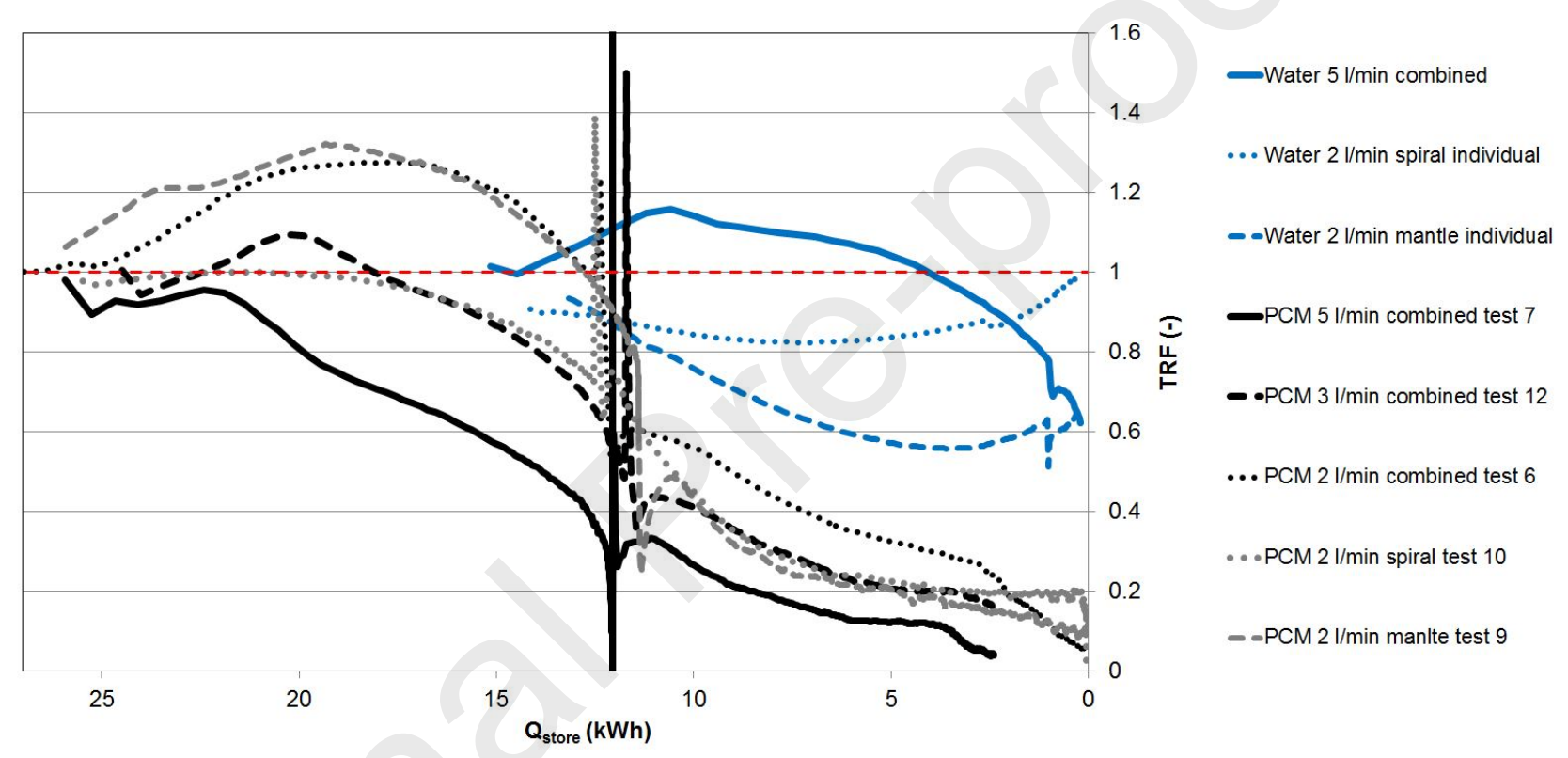

Fig. 11. Development of $T R F$ during discharge.

Because of thermal stratification $(T R F>1) H X C R$ calculation was not possible for SAT composite in liquid state. Fig. 12 presents therefore $H X C R$ of discharge tests with SAT composite during solidification and with water. As during charging, change of HTF flow rate did not cause significant changes when both heat exchangers were applied. $H X C R$ started between 250 and $300 \mathrm{~W} / \mathrm{K}$, which was as high as during charge. Afterwards, HXCR for all flow rates steadily decreased to a value of about $90 \mathrm{~W} / \mathrm{K}$. At the end of discharge $\left(Q_{\text {store }} \sim 3 \mathrm{kWh}\right) H X C R s$ dropped rapidly to about $20 \mathrm{~W} / \mathrm{K}$, which was due to the geometry of the store: The core of the inner tank remained at around $55^{\circ} \mathrm{C}$, while the outer volume was close to the HTF temperature.

$H X C R$ values during discharge by using individual heat exchangers $\left(\dot{V}_{H T F}=21 / \mathrm{min}\right)$ started above $100 \mathrm{~W} / \mathrm{K}$ and decreased steadily to $20 \mathrm{~W} / \mathrm{K}$. This means that a reduction of factor 3 in comparison to combined discharge. 


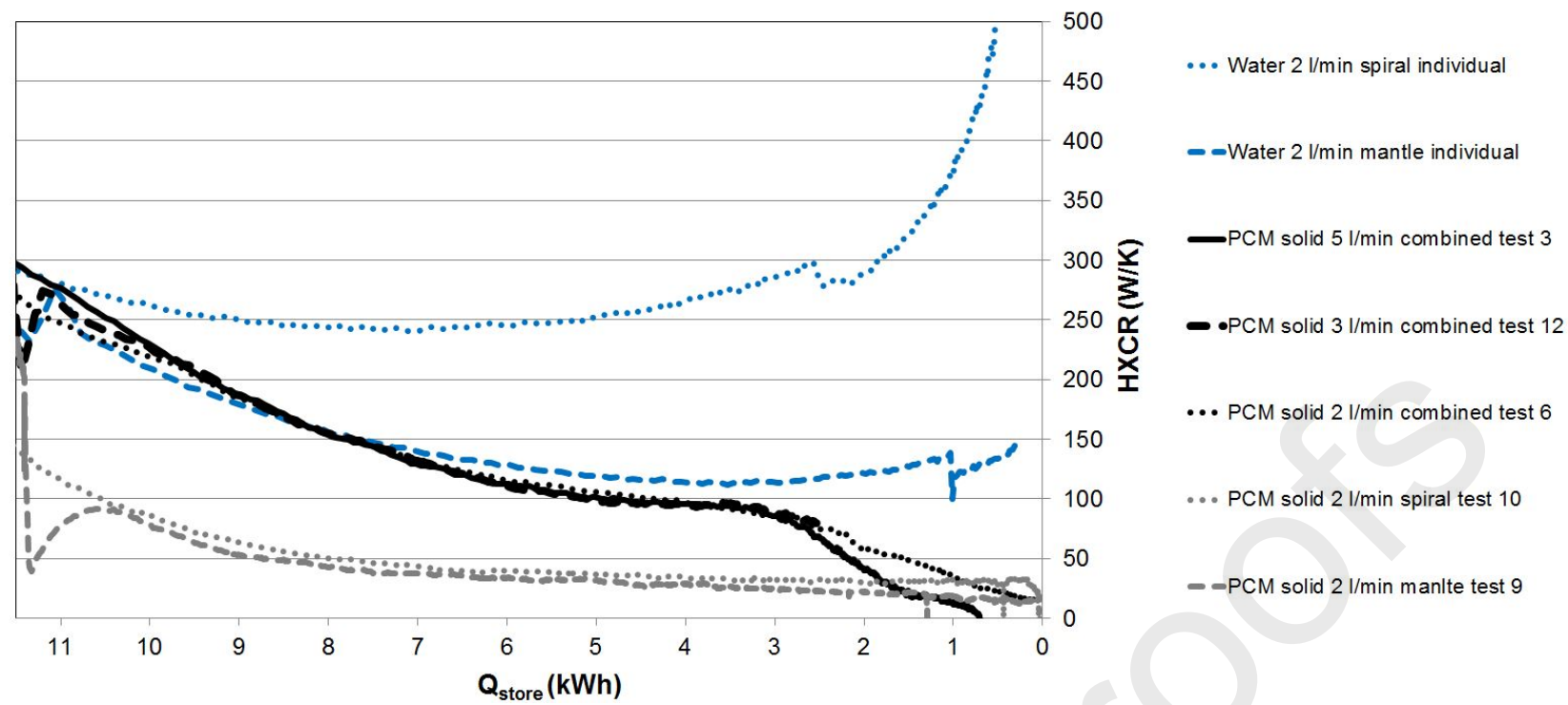

Fig. 12. Development of $H X C R$ during discharge.

Table 5 presents an overview of average $H X C R$ and $T R F$ during charge and discharge using both heat exchangers.

The following settings have been found to be advantageous when using SAT composites:

- For charging, a HTF flow rate of $10 \mathrm{l} / \mathrm{min}$ ensured homogeneous heat exchanger temperatures, which is needed for reliable passivation of nucleation seeds. The average $H X C R$ was a factor of four and $T R F$ a factor of 2.8 lower than during charge of water.

- Tests at 2 1/min performed better during discharge of PCM. In liquid state heat was discharged with a TRF of 1.23, which was higher than during discharge of the water tank with $5 \mathrm{l} / \mathrm{min}$. However, during solidification of SAT composite temperature recovery factors were three times lower than in liquid state and the average $H X C R$ about half in comparison to charge.

Table 5. Average heat exchange capacity rates and temperature recovery factors during selected tests.

\begin{tabular}{|c|c|c|c|c|}
\hline Interval of $\bar{T}_{P C M}$ & \multicolumn{2}{|c|}{ SAT composite } & \multicolumn{2}{|l|}{ Water } \\
\hline $30 \rightarrow 80^{\circ} \mathrm{C}$ & $\begin{array}{c}\text { average } H X C R \text { with } \dot{V}_{H T F}= \\
10 \mathrm{l} / \mathrm{min} \text { during charge }\end{array}$ & $\begin{array}{c}298 \mathrm{~W} / \mathrm{K} \\
\text { (combined, test 7) }\end{array}$ & $\begin{array}{c}\text { average } H X C R \text { with } \dot{V}_{H T F}= \\
10 \mathrm{l} / \mathrm{min} \text { during charge }\end{array}$ & 1215 W/K \\
\hline $30 \rightarrow 80^{\circ} \mathrm{C}$ & $\begin{array}{c}\text { average } T R F \text { with } \dot{V}_{H T F}=10 \mathrm{l} / \mathrm{min} \\
\text { during charge }\end{array}$ & $\begin{array}{c}0.20 \\
\text { (combined, test 7) }\end{array}$ & $\begin{array}{c}\text { average TRF with } \dot{V}_{\text {HTF }}= \\
10 \mathrm{l} / \mathrm{min} \text { during charge }\end{array}$ & 0.56 \\
\hline $80 \rightarrow 30^{\circ} \mathrm{C}$ & $\begin{array}{c}\text { average TRF with } \\
\dot{V}_{\text {HTF }}=2 \mathrm{l} / \mathrm{min} \text { in liquid state }\end{array}$ & $\begin{array}{c}1.23 \\
\text { (combined, test 6) }\end{array}$ & $\begin{array}{c}\text { average } T R F \text { with } \\
\dot{V}_{H T F}=5 \mathrm{l} / \mathrm{min} \text { during discharge }\end{array}$ & 1.10 \\
\hline $58 \rightarrow 35^{\circ} \mathrm{C}$ & $\begin{array}{c}\text { average } H X C R \text { with } \dot{V}_{\text {HFF }}=2 \mathrm{l} / \mathrm{min} \\
\text { during solidification }\end{array}$ & $\begin{array}{c}156 \mathrm{~W} / \mathrm{K} \\
\text { (combined, test 6) }\end{array}$ & & \\
\hline $58 \rightarrow 35^{\circ} \mathrm{C}$ & $\begin{array}{c}\text { average } T R F \text { with } \\
\dot{V}_{\mathrm{HTF}}=2 \mathrm{l} / \mathrm{min} \text { during solidification }\end{array}$ & $\begin{array}{c}0.43 \\
\text { (combined, test 6) }\end{array}$ & & \\
\hline
\end{tabular}




\subsection{Discharge power}

Fig. 13 presents the developments of the discharge power quantity $(|\dot{Q}|)$ over $\bar{T}_{\text {water }}$ and over $\bar{T}_{P C M}$ in liquid state. With $\dot{V}_{H T F}$ in the range of $1.5-2 \mathrm{l} / \mathrm{min}$ a high degree of similarity for use of SAT composite and water was found. With only spiral- or mantle heat exchanger applied, discharge power was $7-9 \mathrm{~kW}$ at $\bar{T}=80^{\circ} \mathrm{C}$ and $1-2 \mathrm{~kW}$ at $\bar{T}=30{ }^{\circ} \mathrm{C}$, whereas with both heat exchangers it reached approximately $15 \mathrm{~kW}$ at $\bar{T}=80^{\circ} \mathrm{C}$. With flow rates of $3-5 \mathrm{l} / \mathrm{min}$ the development of $|\dot{Q}|$ did not change significantly with SAT composite, whereas with water significantly larger discharge power resulted. However, the discharge power was considered to be sufficient to enable heat supply in households during all tests.

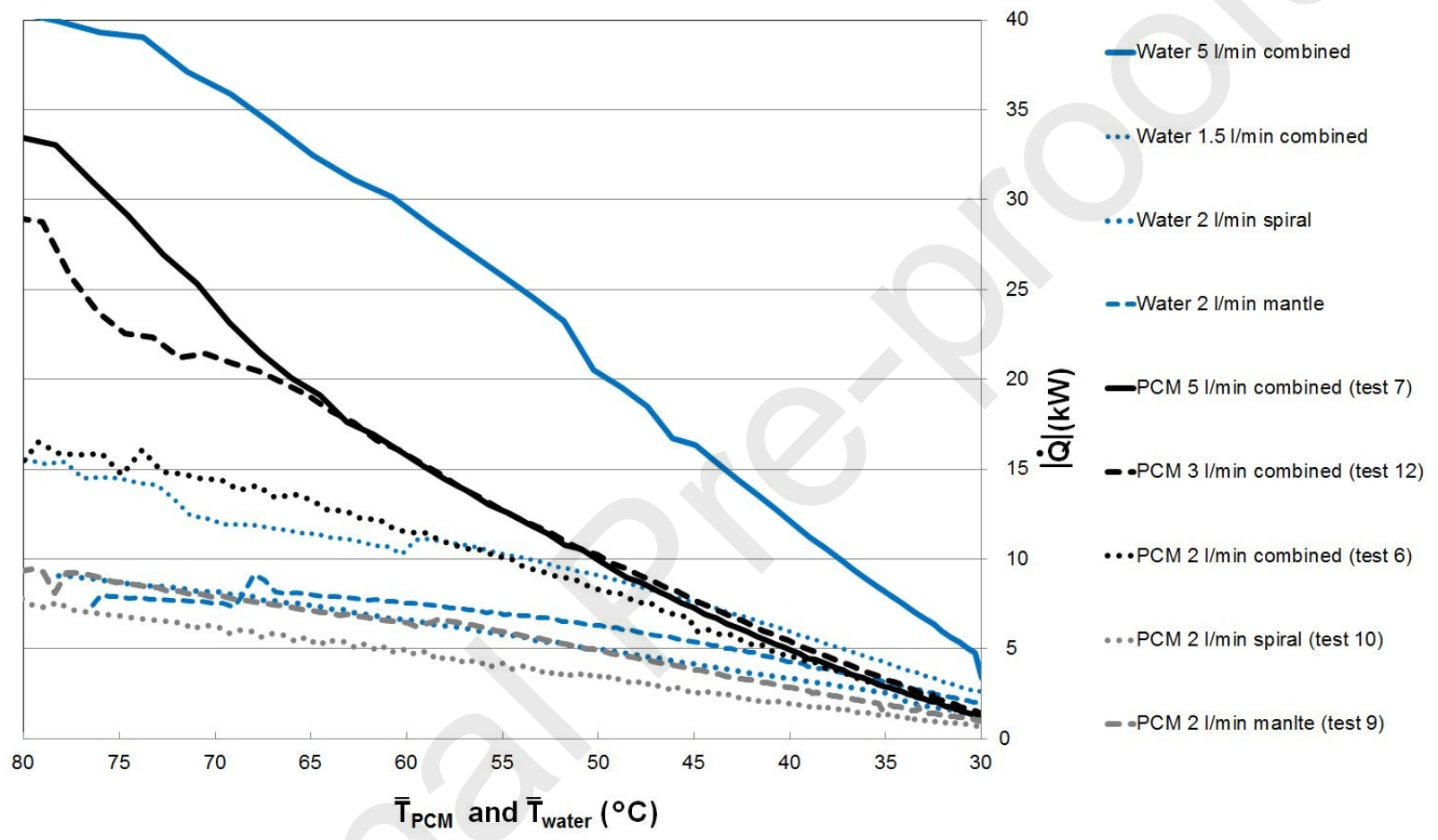

Fig. 13. Discharge powers with water and with liquid SAT composite applied.

Fig. 14 presents the development of discharge power (quantity) over $\bar{T}_{P C M}$ during solidification of the SAT composite. As indicated by analysis of $H X C R$ (displayed in section 4.5), no significant influence of HTF flow rates on discharge power was found. Instead, the curves differed due to variation of the inlet temperature $\left(T_{i n}\right)$, where lower $T_{\text {in }}$ resulted in larger $|\dot{Q}|$. During test 6 and $12 T_{\text {in }}$ remained almost constant at the set temperature $\left(25^{\circ} \mathrm{C}\right)$, while it increased to $28^{\circ} \mathrm{C}$ during test 7 and it decreased to $22{ }^{\circ} \mathrm{C}$ during test 6 . This unwanted behaviour resulted from automated flow control of the laboratory cooling circuit.

The shape of the curves had a high degree of similarity: During combined discharge $|\dot{Q}|$ started below $5 \mathrm{~kW}$, followed by a sharp decrease to $1.5-2.2 \mathrm{~kW}$ at $50^{\circ} \mathrm{C}$ and decreased afterwards steadily. Discharge power dropped below $1 \mathrm{~kW}$ at $Q_{\text {store }} \sim 3 \mathrm{kWh}$ during tests 1,6 and 12 and at $Q_{\text {store }} \sim 4 \mathrm{kWh}$ during test 7 . Individual heat exchanger application (test 9 and test 10) reduced discharge power to approximately less than half, in comparison to tests 6 and 12. 


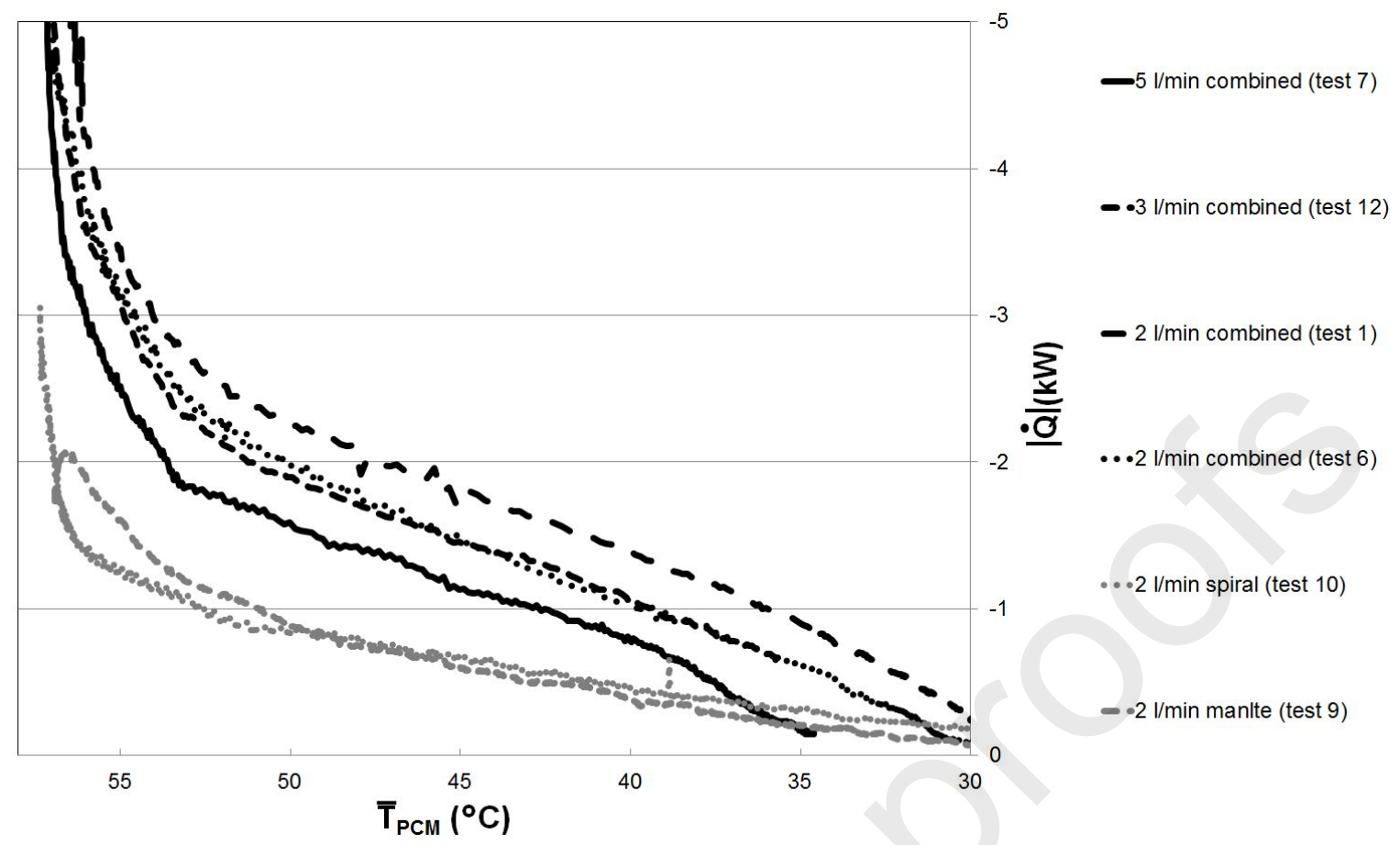

Fig. 14. Discharge power during solidification.

\subsection{Discontinuous discharge}

Fig. 15 presents data from the $8^{\text {th }}$ test cycle, in which continuous charge was followed by discontinuous discharge via the mantle heat exchanger with a flow rate of $2 \mathrm{l} / \mathrm{min}$. After full charge was achieved (orange area), the store remained hot for about 10 hours, while its heat content was reduced due to sensible heat losses in liquid state (grey area). Then, it was discharged twice in liquid state and interrupted when $T_{\text {out }}$ fell to the value of $\bar{T}_{P C M}$. Crystallization of the SAT composite was initiated at $\bar{T}_{P C M}=33^{\circ} \mathrm{C}$. Discharge of the latent heat of fusion (blue area) was conducted in seven parts, with intervals of 2-24 hours. Thermal power reached around $-4 \mathrm{~kW}$ during six discharge events, and heatdraws ranged between 1 and $2 \mathrm{kWh}$ for each discharge segment. 


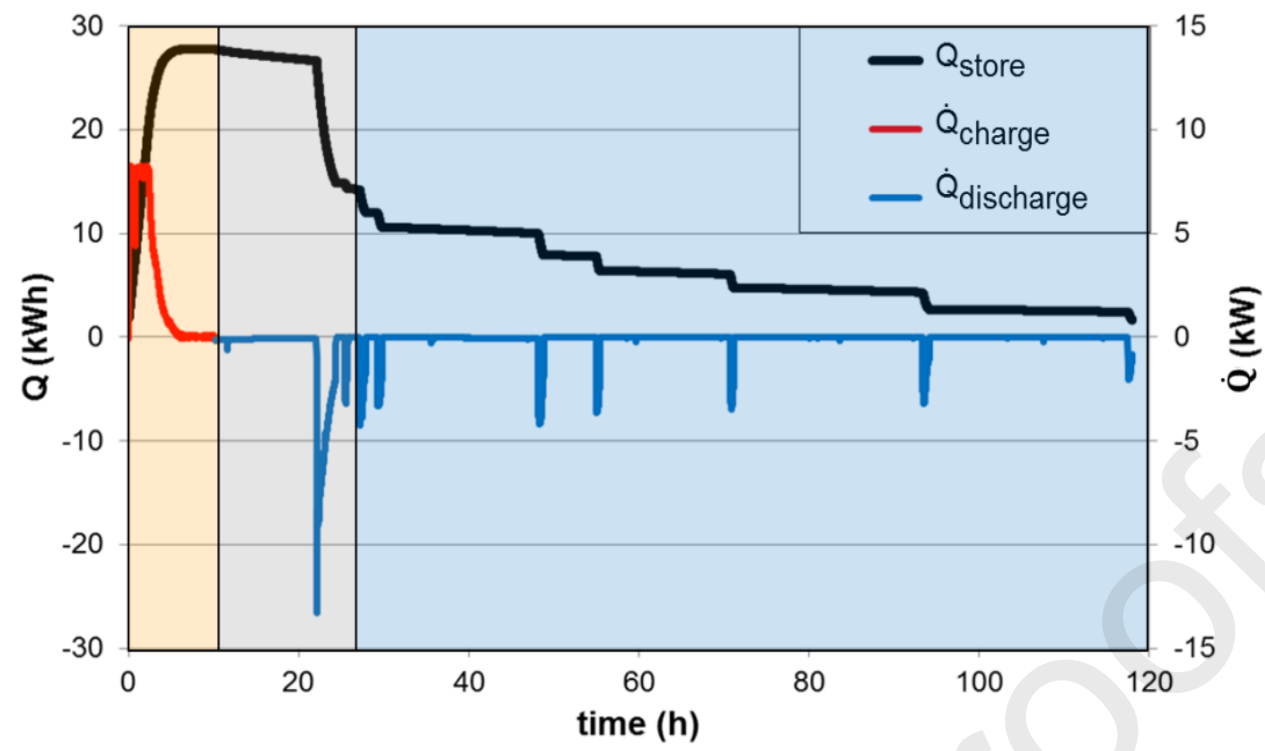

Fig. 15. Development of thermal power and heat content during the $8^{\text {th }}$ test cycle.

As shown in Fig. 16, it was possible to utilize thermal stratification and therefore increased flow temperatures during the entire discharge. In liquid state, $T R F$ was above one and therefore $T_{\text {out }}>\bar{T}_{P C M}$. During solidification $T R F$ was close to one during the first five discharge events, while during the last two discharge events $T R F$ exceeded one, because the intervals were 24 hours and the HTF had therefore sufficient time to build up maximal stratification in the mantle volume. Danish code of practice for DHW supply, DS 439 [50], recommends a hot water temperature of $45^{\circ} \mathrm{C}$. Thus, partial-load of the heat storage $\left(\mathrm{Q}_{\text {store }}>5 \mathrm{~kW}\right)$ is required. $T_{\text {out }}$ exceeded $30{ }^{\circ} \mathrm{C}$ during all discharge segments, which is considered as requirement for SH supply in domestic dwellings. However, for a single-family household the necessary time intervals between discharge events would be too long to cover heat demands. Therefore, a storage system consisting of several tank-in-tank stores would be needed. This would be an economically attractive solution to utilize stable supercooling of SAT composites without need for (potentially expensive) enhancement of the thermal conductivity.

After the last discharge event, $\bar{T}_{P C M}$ remained at $30^{\circ} \mathrm{C}$, which corresponds to a heat content of $1.2 \mathrm{kWh}$. Since recharge would be needed for further heat supply, the applicable energy storage capacity for space heating was determined to be $25.8 \mathrm{kWh}$. 


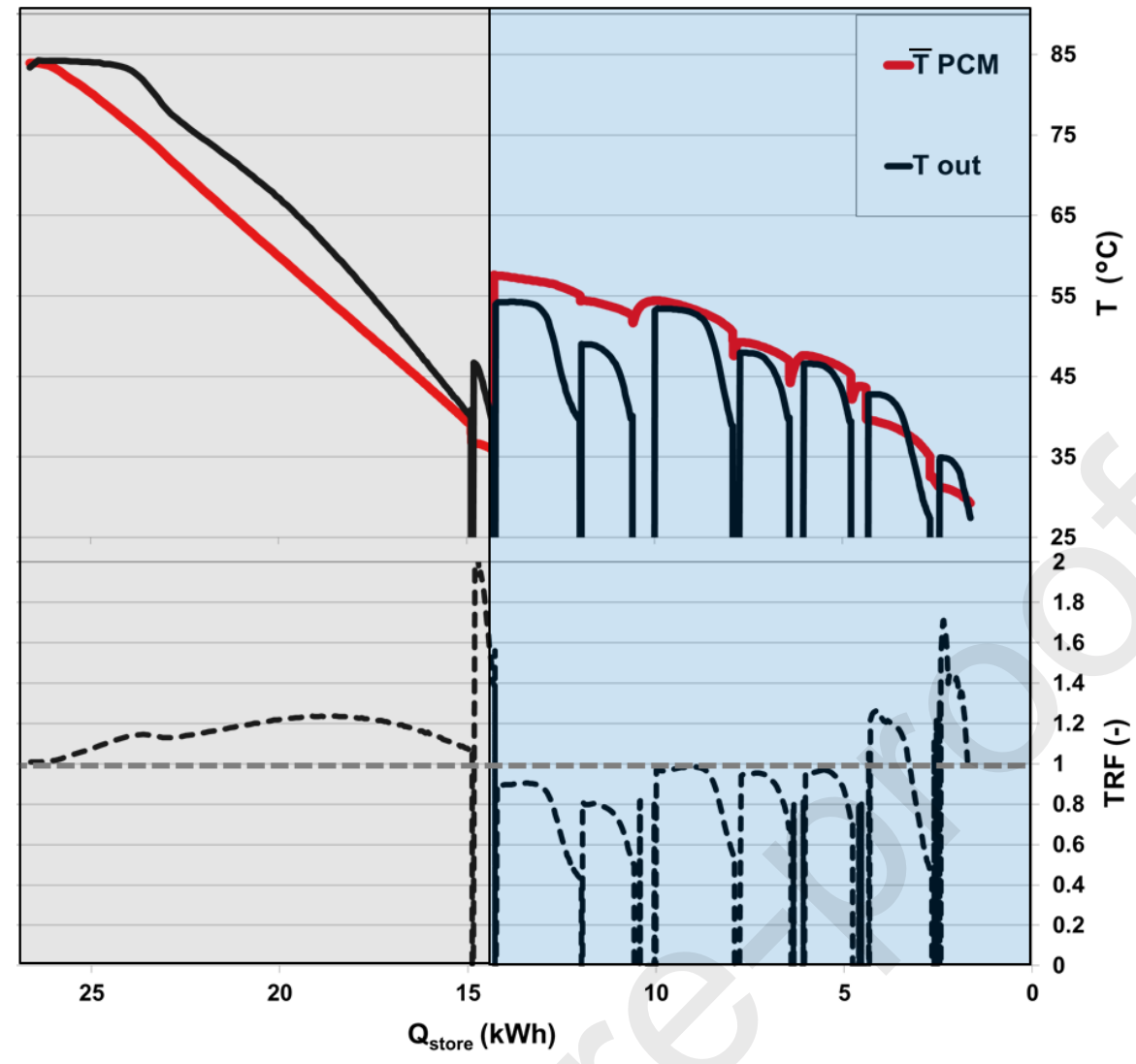

Fig. 16. Outlet temperature and $T R F$ during discontinuous discharge. 


\section{Conclusions}

Utilization of stable supercooling of SAT composites for combined short and long-term heat storage was demonstrated with a tank-in-tank store which was built with standard components for water heat stores. The store was subjected to charge/ discharge tests under different experimental conditions, including 12 test cycles with SAT composite. Their evaluation resulted in the following findings:

- During all 12 test cycles low supercooling temperatures were achieved although temperature measurement devices and corrosion on the inner tank surface influenced supercooling stability. Reliable supercooling of SAT composite could be potentially achieved without internal temperature monitoring and with oil instead of air in the expansion volume of the inner tank.

- The energy storage capacity of the store was measured to be $27 \mathrm{kWh}$ by heating up from 25 to $90^{\circ} \mathrm{C}$, from which 15.5 $\mathrm{kWh}$ of heat was discharged in liquid state and $11.5 \mathrm{kWh}$ of heat was stored in the supercooled PCM. The capacity of the composite was determined to be $21.3 \mathrm{kWh}$, which was $76 \%$ higher than the capacity obtained when water was filled in the store. Based on these capacities, the latent heat of fusion of the composite was calculated to be $238 \mathrm{~kJ} / \mathrm{kg}$, from which $207 \mathrm{~kJ} / \mathrm{kg}$ could be utilized during solidification from supercooled state at $25{ }^{\circ} \mathrm{C}$.

- Heat exchange capacity rates during charging and discharging of SAT composite did not change for heat transfer fluid flow rates of 3-10 1/min, which means that the heat transfer was limited by the SAT composite properties. Heating up from $30{ }^{\circ} \mathrm{C}$ to $80{ }^{\circ} \mathrm{C}$ resulted in an average heat exchange capacity rate of $298 \mathrm{~W} / \mathrm{K}$, which was a factor of four lower than for the case of water with a heat transfer fluid flow rate of $101 / \mathrm{min}$.

- During discharging, an increase of flow rate increased thermal power only significantly below $3 \mathrm{l} / \mathrm{min}$ in liquid state, whereas during solidification no dependency of thermal power on the flow rate was found. As a result, the temperature recovery factor and therefore the outlet temperature decreased with higher flow rates in liquid and solid PCM state.

- The mantle heat exchanger performed best with $21 /$ min during discharge in liquid PCM state. The temperature recovery factor from $80{ }^{\circ} \mathrm{C}$ to $30{ }^{\circ} \mathrm{C}$ was then 1.247 , which means that the outlet temperature was higher than the average PCM temperature due to thermal stratification of liquid SAT composite.

- Combined use of spiral- and mantle heat exchanger with a flow rate of $2 \mathrm{l} / \mathrm{min}$ is considered to be the most advantageous operation condition for continuous discharge, because it provided quite high thermal power and outlet temperatures above the corresponding SAT composite temperature in liquid state. However, during solidification discharge power was rather low and the temperature recovery factor was three times lower than in liquid state.

By discharge via the mantle heat exchanger in intervals of 2-24 hours it was possible to utilize heat of fusion with thermal power up to $4 \mathrm{~kW}$ (flow rate of $21 / \mathrm{min}$ ) and with outlet temperatures close to those of the SAT composite. Application of several stores in parallel could enable heat supply in buildings utilizing discontinuous discharge of single stores. In this way, heat transfer restrictions during solidification of SAT composite could be solved and economically attractive heat stores could be applied for long-term heat storage.

\section{Acknowledgements}

This research was supported by the PhD program of the Sino Danish Center for Education and Research (SDC). We thank our partner at NILAN A/S for the good collaboration. Further we would like to thank the DTU research technician Claus Aagaard as well as Jakob Brinkø Berg, Yiliang Jiang and Andrea Hernandez Pedrero for their practical support. 


\section{References}

[1] B. Zalba, J.M. Marín, L.F. Cabeza, H. Mehling, Review on thermal energy storage with phase change: materials, heat transfer analysis and applications, Appl. Therm. Eng. 23 (2003) 251-283.

[2] D. Zhou, C.Y. Zhao, Y. Tian, Review on thermal energy storage with phase change materials (PCMs) in building applications, Appl. Energy. 92 (2012) 593-605. doi:10.1016/j.apenergy.2011.08.025.

[3] G. Englmair, Y. Jiang, M. Dannemand, C. Moser, H. Schranzhofer, S. Furbo, J. Fan, Crystallization by local cooling of supercooled sodium acetate trihydrate composites for long-term heat storage, Energy Build. 180 (2018) 159-171. doi:10.1016/j.enbuild.2018.09.035.

[4] M.A. Rogerson, S.S.S. Cardoso, Solidification in heat packs: I. Nucleation rate, AIChE J. 49 (2003) 505-515. doi:10.1002/aic.690490220.

[5] K. Seo, S. Suzuki, T. Kinoshita, I. Hirasawa, Effect of Ultrasonic Irradiation on the Crystallization of Sodium Acetate Trihydrate Utilized as Heat Storage Material, Chem. Eng. Technol. 35 (2012) 1013-1016. doi:10.1002/ceat.201100680.

[6] G. Zhou, M. Zhu, Y. Xiang, Effect of percussion vibration on solidification of supercooled salt hydrate PCM in thermal storage unit, Renew. Energy. 126 (2018) 537-544. doi:10.1016/j.renene.2018.03.077.

[7] M.A. Rogerson, S.S.S. Cardoso, Solidification in heat packs: II. Role of cavitation, AIChE J. 49 (2003) 516521. doi:10.1002/aic.690490221.

[8] M. Dannemand, M. Delgado, A. Lazaro, C. Penalosa, C. Gundlach, C. Trinderup, J.B. Johansen, C. Moser, H. Schranzhofer, S. Furbo, Porosity and density measurements of sodium acetate trihydrate for thermal energy storage, Appl. Therm. Eng. 131 (2018) 707-714. doi:10.1016/j.applthermaleng.2017.12.052.

[9] W. Cui, Y. Yuan, L. Sun, X. Cao, X. Yang, Experimental studies on the supercooling and melting/freezing characteristics of nano-copper/sodium acetate trihydrate composite phase change materials, Renew. Energy. 99 (2016) 1029-1037. doi:10.1016/j.renene.2016.08.001.

[10] J. Guion, M. Teisseire, Nucleation of sodium acetate trihydrate in thermal heat storage cycles, Sol. Energy. 46 (1991) 97-100.

[11] N. Beaupere, U. Soupremanien, L. Zalewski, Nucleation triggering methods in supercooled phase change materials (PCM), a review, Thermochim. Acta. 670 (2018) 184-201. doi:10.1016/j.tca.2018.10.009.

[12] A.Y. Uzan, Y. Kozak, Y. Korin, I. Harary, H. Mehling, G. Ziskind, A novel multi-dimensional model for solidification process with supercooling, Int. J. Heat Mass Transf. 106 (2017) 91-102. doi:10.1016/j.ijheatmasstransfer.2016.10.046.

[13] B. Sandnes, J. Rekstad, Supercooling salt hydrates: Stored enthalpy as a function of temperature, Sol. Energy. 80 (2006) 616-625. doi:10.1016/j.solener.2004.11.014.

[14] G. Zhou, Y. Xiang, Experimental investigations on stable supercooling performance of sodium acetate trihydrate PCM for thermal storage, Sol. Energy. 155 (2017) 1261-1272. doi:10.1016/j.solener.2017.07.073.

[15] G. Zhou, Y. Han, Numerical simulation on thermal characteristics of supercooled salt hydrate PCM for energy storage: Multiphase model, Appl. Therm. Eng. 125 (2017) 145-152. doi:10.1016/j.applthermaleng.2017.07.010.

[16] T.M. Lecther, Storing Energy-with special reference to renewable energy sources, in: Elsevier, 2015 : pp. 1-565. doi:https://doi.org/10.1016/C2014-0-04236-0.

[17] M. Dannemand, J.B. Johansen, W. Kong, S. Furbo, Experimental investigations on cylindrical latent heat storage units with sodium acetate trihydrate composites utilizing supercooling, Appl. Energy. 177 (2016) 591601. doi:10.1016/j.apenergy.2016.05.144.

[18] G. Englmair, C. Moser, S. Furbo, M. Dannemand, J. Fan, Design and functionality of a segmented heat-storage prototype utilizing stable supercooling of sodium acetate trihydrate in a solar heating system, Appl. Energy. 221 (2018) 522-534. doi:10.1016/j.apenergy.2018.03.124.

[19] W. Kong, M. Dannemand, J. Berg Johansen, J. Fan, S. Furbo, Experimental investigations on phase separation for different heights of sodium acetate water mixtures under different conditions, Appl. Therm. Eng. (2018). doi:10.1016/j.applthermaleng.2018.10.017. 
[20] M. Dannemand, J.B. Johansen, S. Furbo, Solidification behavior and thermal conductivity of bulk sodium acetate trihydrate composites with thickening agents and graphite, Sol. Energy Mater. Sol. Cells. 145 (2016) 287-295. doi:10.1016/j.solmat.2015.10.038.

[21] W. Kong, M. Dannemand, J.B. Johansen, J. Fan, J. Dragsted, G. Englmair, S. Furbo, Experimental investigations on heat content of supercooled sodium acetate trihydrate by a simple heat loss method, Sol. Energy. 139 (2016) 249-257. doi:10.1016/j.solener.2016.09.045.

[22] J. Pereira da Cunha, P. Eames, Thermal energy storage for low and medium temperature applications using phase change materials - A review, Appl. Energy. 177 (2016) 227-238. doi:10.1016/j.apenergy.2016.05.097.

[23] M. Saffari, A. de Gracia, C. Fernández, L.F. Cabeza, Simulation-based optimization of PCM melting temperature to improve the energy performance in buildings, Appl. Energy. 202 (2017) 420-434. doi:10.1016/j.apenergy.2017.05.107.

[24] P.A.J. Donkers, L.C. Sögütoglu, H.P. Huinink, H.R. Fischer, O.C.G. Adan, A review of salt hydrates for seasonal heat storage in domestic applications, Appl. Energy. 199 (2017) 45-68. doi:10.1016/j.apenergy.2017.04.080.

[25] C. Liu, D. Groulx, Experimental study of the phase change heat transfer inside a horizontal cylindrical latent heat energy storage system, Int. J. Therm. Sci. 82 (2014) 100-110. doi:10.1016/j.ijthermalsci.2014.03.014.

[26] A. López-navarro, J. Biosca-taronger, J.M. Corberán, C. Peñalosa, A. Lázaro, P. Dolado, J. Payá, Performance characterization of a PCM storage tank, Appl. Energy. 119 (2014) 151-162. doi:10.1016/j.apenergy.2013.12.041.

[27] C. Zauner, F. Hengstberger, B. Mörzinger, R. Hofmann, H. Walter, Experimental characterization and simulation of a hybrid sensible-latent heat storage, Appl. Energy. 189 (2017) 506-519. doi:10.1016/j.apenergy.2016.12.079.

[28] A. Frazzica, M. Manzan, A. Sapienza, A. Freni, G. Toniato, G. Restuccia, Experimental testing of a hybrid sensible-latent heat storage system for domestic hot water applications, Appl. Energy. 183 (2016) 1157-1167. doi:10.1016/j.apenergy.2016.09.076.

[29] H. Niyas, C.R.C. Rao, P. Muthukumar, Performance investigation of a lab-scale latent heat storage prototype Experimental results, Sol. Energy. 155 (2017) 971-984. doi:10.1016/j.solener.2017.07.044.

[30] Z. Ma, H. Bao, A.P. Roskilly, Study on solidification process of sodium acetate trihydrate for seasonal solar thermal energy storage, Sol. Energy Mater. Sol. Cells. 172 (2017) 99-107. doi:10.1016/j.solmat.2017.07.024.

[31] M. Delgado, A. Lázaro, J. Mazo, C. Peñalosa, J.M. Marín, B. Zalba, Experimental analysis of a coiled stirred tank containing a low cost PCM emulsion as a thermal energy storage system, Energy. 138 (2017) 590-601. doi:10.1016/j.energy.2017.07.044.

[32] A. Castell, M. Belusko, F. Bruno, L.F. Cabeza, Maximisation of heat transfer in a coil in tank PCM cold storage system, Appl. Energy. 88 (2011) 4120-4127. doi:10.1016/j.apenergy.2011.03.046.

[33] D. Lafri, D. Semmar, A. Hamid, M. Ouzzane, Experimental investigation on combined sensible and latent heat storage in two different configurations of tank filled with PCM, Appl. Therm. Eng. 149 (2019) 625-632. doi:10.1016/j.applthermaleng.2018.12.028.

[34] M. Kabbara, D. Groulx, A. Joseph, A parametric experimental investigation of the heat transfer in a coil-in-tank latent heat energy storage system, Int. J. Therm. Sci. 130 (2018) 395-405. doi:10.1016/j.ijthermalsci.2018.05.006.

[35] M. Tayssir, S.M. Eldemerdash, R.Y. Sakr, A.R. Elshamy, O.E. Abdellatif, Experimental investigation of melting behavior of PCM by using coil heat source inside cylindrical container, J. Electr. Syst. Inf. Technol. 4 (2017) 18-33. doi:10.1016/j.jesit.2016.10.008.

[36] V. Palomba, V. Brancato, A. Frazzica, Experimental investigation of a latent heat storage for solar cooling applications, Appl. Energy. 199 (2017) 347-358. doi:10.1016/j.apenergy.2017.05.037.

[37] P.F. Barrett, B.R. Best, Thermal energy storage in supercooled salt mixtures, Mater. Chem. Phys. 12 (1985) 529-536. doi:10.1016/0254-0584(85)90038-0.

[38] L. Desgrosseilliers, Design and evaluation of a modular, supercooling phase change heat storage device for indoor heating, Dalhousie University, 2016. 
[39] M. Dannemand, J. Dragsted, J. Fan, J.B. Johansen, W. Kong, S. Furbo, Experimental investigations on prototype heat storage units utilizing stable supercooling of sodium acetate trihydrate mixtures, Appl. Energy. 169 (2016) 72-80. doi:10.1016/j.apenergy.2016.02.038.

[40] G. Englmair, C. Moser, S. Furbo, M. Dannemand, J. Fan, Design and functionality of a segmented heat-storage prototype utilizing stable supercooling of sodium acetate trihydrate in a solar heating system, Appl. Energy. 221 (2018) 522-534. doi:10.1016/j.apenergy.2018.03.124.

[41] G. Englmair, W. Kong, J.B. Berg, S. Furbo, J. Fan, Demonstration of a solar combi-system utilizing stable supercooling of sodium acetate trihydrate for heat storage, submitted to Appl. Therm. Eng., revised manuscript in review.

[42] C. Rathgeber, E. Lävemann, A. Hauer, Economic top-down evaluation of the costs of energy storages-A simple economic truth in two equations, J. Energy Storage. 2 (2015) 43-46. doi:10.1016/j.est.2015.06.001.

[43] The International Association for the Properties of Water and Steam, The IAPWS Industrial Formulation 1997 for the Thermodynamic Properties of Water and Steam, IAPWS R7-97 (2012).

[44] N. Araki, M. Futamura, A. Makino, H. Shibata, Measurements of Thermophysical Properties of Sodium Acetate Hydrate, Internaltional J. Thermophys. 16 (1995) 1455-1466.

[45] L.F. Cabeza, G. Svensson, S. Hiebler, H. Mehling, Thermal performance of sodium acetate trihydrate thickened with different materials as phase change energy storage material, Appl. Therm. Eng. 23 (2003) 1697-1704. doi:10.1016/S1359-4311(03)00107-8.

[46] IG Chemicals, Specification sheet SAT E262i, Bad Salzuflen, Germany, 2015.

[47] JCGM. Joint committee for guides in metrology: evaluation of measurement data - Guide to the expression of uncertainty in measurement (GUM), JCGM 100, 2008.

[48] Kamstrup A/S, Technical Description of Ultraflow sensors, [Online]. Available: https://products.kamstrup.com/index.php. [Accessed: 27-Feb-2019].

[49] S. Furbo, V. Korsgaard, Varmelagring til solvarmenalæg, Technical University of Denmark, Thermal Insulation Laboratory report no. 162, 1984.

[50] DS 439, Norm for vandinstallationer - Code of Practice for domestic water supply, Danish Standards (2009) 75. 


\section{Highlights}

- Heat storage built with standard components for water heat stores

- $\quad$ SAT composite provided an energy storage capacity $76 \%$ higher than water

- Demonstration of combined short and long-term heat storage

- Sensitivity analysis of heat transfer via mantle and spiral heat exchangers

- Discontinuous discharge as solution for heat supply in buildings 


\section{Author Contribution Statement}

Gerald Englmair (First and corresponding author): Conceptualization, Methodology, Experimental Investigation, Data Curation, Formal analysis, Writing - Original Draft, Editing and Correspondence to journal Simon Furbo: Project administration, Conceptualization, Formal analysis, Writing- Review and Editing Mark Dannemand: Conceptualization, Methodology, Writing- Review and Editing

Jianhua Fan (Second corresponding author): Funding acquisition, Supervision, Writing- Review and Editing

Lyngby, $19^{\text {th }}$ of November 2019

Gerald Englmair 